Article

\title{
Ammonia Bioremediation from Aquaculture Wastewater Effluents Using Arthrospira platensis NIOF17/003: Impact of Biodiesel Residue and Potential of Ammonia-Loaded Biomass as Rotifer Feed
}

\author{
Mohamed Ashour 1,*(D), Ahmed E. Alprol ${ }^{1}$, Ahmed M. M. Heneash ${ }^{1}$, Hosam Saleh ${ }^{1}$, Khamael M. Abualnaja ${ }^{2}$, \\ Dalal Alhashmialameer ${ }^{2}$ and Abdallah Tageldein Mansour $3,4, * \mathbb{D}$
}

1 National Institute of Oceanography and Fisheries (NIOF), Cairo 11516, Egypt; ah831992@gmail.com (A.E.A.); aheneash@yahoo.com (A.M.M.H.); husam_aldien2@hotmail.com (H.S.)

2 Department of Chemistry, College of Science, Taif University, P.O. Box 11099, Taif 21944, Saudi Arabia; k.ala@tu.edu.sa (K.M.A.); Dsamer@tu.edu.sa (D.A.)

3 Animal and Fish Production Department, College of Agricultural and Food Sciences, King Faisal University, P.O. Box 420, Al-Ahsa 31982, Saudi Arabia

4 Fish and Animal Production Department, Faculty of Agriculture (Saba Basha), Alexandria University, Alexandria 21531, Egypt

check for updates

Citation: Ashour, M.; Alprol, A.E.; Heneash, A.M.M.; Saleh, H.; Abualnaja, K.M.; Alhashmialameer, D.; Mansour, A.T. Ammonia Bioremediation from Aquaculture Wastewater Effluents Using Arthrospira platensis NIOF17/003: Impact of Biodiesel Residue and Potential of Ammonia-Loaded Biomass as Rotifer Feed. Materials 2021, 14, 5460. https://doi.org/ $10.3390 /$ ma14185460

Academic Editors: Marco Zannotti and Rita Giovannetti

Received: 22 August 2021

Accepted: 10 September 2021

Published: 21 September 2021

Publisher's Note: MDPI stays neutral with regard to jurisdictional claims in published maps and institutional affiliations.

Copyright: (c) 2021 by the authors. Licensee MDPI, Basel, Switzerland. This article is an open access article distributed under the terms and conditions of the Creative Commons Attribution (CC BY) license (https:// creativecommons.org/licenses/by/ $4.0 /)$.
* Correspondence: ma.fikry@niof.sci.eg (M.A.); amansour@kfu.edu.sa (A.T.M.)

Abstract: The present work evaluated the capability of Arthrospira platensis complete biomass (ACDW) and the lipid-free biomass (LFB) to remove ammonium ions $\left(\mathrm{NH}_{4}{ }^{+}\right)$from aquaculture wastewater discharge. Under controlled conditions in flasks filled with $100 \mathrm{~mL}$ of distilled water (synthetic aqueous solution), a batch process ion-exchange was conducted by changing the main parameters including contact times $(15,30,45,60,120$, and $180 \mathrm{~min})$, initial ammonium ion concentrations $\left(10,20,30,40,50\right.$, and $\left.100 \mathrm{mg} \cdot \mathrm{L}^{-1}\right)$, and initial $\mathrm{pH}$ levels $(2,4,6,8$, and 10$)$ at various dosages of ACDW and LFB as adsorbents $(0.02,0.04,0.06,0.08$, and $0.1 \mathrm{~g})$. After lab optimization, ammonia removal from real aquaculture wastewater was also examined. The removal of ammonium using ACDW and LFB in the synthetic aqueous solution $(64.24 \%$ and $89.68 \%$, respectively) was higher than that of the real aquaculture effluents $(25.70 \%$ and $37.80 \%$, respectively). The data of IR and Raman spectroscopy confirmed the existence of various functional groups in the biomass of ACDW and LFB. The adsorption equilibrium isotherms were estimated using Freundlich, Langmuir, and Halsey models, providing an initial description of the ammonia elimination capacity of $A$. platensis. The experimental kinetic study was suitably fit by a pseudo-second-order equation. On the other hand, as a result of the treatment of real aquaculture wastewater (RAW) using LFB and ACDW, the bacterial counts of the LFB, ACDW, ACDW-RAW, and RAW groups were high (higher than $300 \mathrm{CFU}$ ), while the LFB-RAW group showed lower than 100 CFU. The current study is the first work reporting the potential of ammonia-loaded microalgae biomass as a feed source for the rotifer (Brachionus plicatilis). In general, our findings concluded that B. plicatilis was sensitive to A. platensis biomass loaded with ammonia concentrations. Overall, the results in this work showed that the biomass of $A$. platensis is a promising candidate for removing ammonia from aquaculture wastewater.

Keywords: Arthrospira platensis NIOF17/003; lipid-free biomass; aquaculture wastewater treatment; ammonia adsorption; IR; FTIR; isotherms study; kinetic study; rotifer

\section{Introduction}

The increase in population in recent years has led to the continuous development and expansion of aquaculture activities, which have directly led to an increase in water consumption, causing many problems, especially the issue of wastewater disposal. This wastewater usually contains a high content of nitrogen, which comes mainly from fish 
excreta and feed residue. To date, several biological and chemical methods have been used in the treatment of aquaculture wastewater. However, these methods have several disadvantages such as being no environmentally friendly, inefficient, and without economic value on large-scale application [1-4]. In general, this aquaculture waste is laden with various types of pollutants, especially high quantities of nitrogenous compounds, mainly in ammonia form $\left(\mathrm{NH}_{4}^{+}\right)$. These nitrogenous compounds, together with other pollutants, cause a high level of eutrophication along the coastal areas, which results in the growth of invasive organisms [5]. Recently, there has been global interest in the removal of pollutants from different types of wastewater attributed to the high potency of these pollutants to contaminate food and water sources in addition to establishing appropriate growth parameters for several pathogenic microorganisms [6].

Nitrogen is a main chemical compound for life and industrial use, while ammonia is an integral component of the nitrogen cycle life and is a source of free nitrogen. Industrial wastewater, agricultural activities, and municipal effluents increase the ammonia nitrogen discharges into environmental resources [7]. Ammonium pollution affects the aquatic quality of water bodies, resulting in severe environmental problems such as $\mathrm{pH}$ shift, cyanotoxin creation, oxygen reduction, eutrophication of downstream liquids, enhanced eutrophication of rivers and lakes, and exhaustion of dissolved oxygen, being toxic aquatic animals at a level greater than $1.9 \mathrm{mg} \cdot \mathrm{L}^{-1}[8,9]$.

In aquaculture wastewaters, ammonia concentration should be decreased to tolerable limits before being discharged into the aquatic environment [10]. Thus, wastewater treatment is aimed at the removal of pollutants and includes may methods such as biological processes (anaerobic and aerobic), chemical oxidation, nanofiltration, combustion, ultrafiltration, precipitation, flocculation, reverse osmosis, evaporation, and adsorption [11]. Biological treatments are used for the traditional method of removing ammonia from industrial and municipal wastewaters. However, toxic shock, $\mathrm{pH}$ changes, low dissolved oxygen, and cold temperatures in the winter can all impede this approach [12]. One of the most effective ways to decrease the amount of aquaculture wastewater contaminants is to develop an adsorbent that is a natural component [13].

Recently, microalgae have been discussed as a valuable feedstock for many applications, including biofuel production [14,15]. It was calculated that roughly $40-100 \mathrm{~kg}$ of inorganic nitrogen compounds and 11-13 ML/Ha/year of water are required for 1 ton of microalgal growth [8]. It was also anticipated that roughly $2500 \mathrm{~m}^{3}$ of wastewater might be processed to produce 1 ton of microalgal biomass [16]. As a result, using wastewater for algal cultivation could allow for the removal of nutrients from effluents while also reducing water consumption by $90 \%$. Furthermore, by employing mixotrophic cultivation, the negative impact of high ammonium concentrations on microalgal growth and biomass yield will be reduced. In fact, mixotrophic growth offers more energy for rapid ammonium assimilation, lowering the ammonium inhibition and increasing the microalgal biomass yield [8].

Algal biomass is a natural source of bioactive substances that can be employed in a variety of applications such as aquaculture, biofertilizer, food supplement, cosmetics, biodiesel, antimicrobial activities, and bioremediation. Arthrospira platensis, a cyanophyte, has emerged as one of the most promising agents for the production of possibly novel chemicals. It has been shown to create intracellular and extracellular metabolites with a variety of biological activities, including antifungal, antiviral, and antibacterial activities [17,18]. Moreover, A. platensis displays a broad spectrum of antimicrobial and antioxidant properties against Gram-positive and Gram-negative pathogens [19]. Functional groups such as hydroxyl, carboxyl, phosphate, and sulfate, as well as other charged groups, can interfere with pollutant binding sites in the biomass. This microalgal species has been used to remove dyes and heavy metals from aqueous solutions with great success [20].

In the last few years, microalgal biomass has been studied as an important adsorbent for the purification of aquaculture wastewater, owing to its capability of applying and/or accumulating heavy metals, nutrients, and various materials in their cells. Adsorption is 
a reducing technology that removes hazardous pollutants from aqueous solutions using living or dead biomasses. Adsorption is a multistep process that includes ion exchange, chelation, physical adsorption, and trapping in inter- and intra-fibrillar capillaries and the space of the structural polysaccharide network as a result of concentration gradients and diffusion [21]. The use of microalgal biomass for wastewater treatment requires the least amount of mechanical equipment and consumes less energy compared to other conventional methods [7]. Many studies have confirmed that microalgal biomass has great potential for $\mathrm{N}$ elimination and stated effective cultivations [22-29]. In the study by Zaki et al. [30], a cyanobacterium strain A. platensis NIOF17/003 (GenBank number: MW396472) was isolated, molecularly identified, and sub-cultured under controlled conditions. The growth rate curve, biochemical composition, lipid profile, and biodiesel production potential of this strain were investigated. Recently, A. platensis NIOF17/003 showed a positive effect on the bioremediation of organic dye (Ismate violet $2 R$, IV2R) from industrial textile effluents [31]. However, the ability of this strain to adsorb nitrogen from wastewater and the impact of nitrogen-rich biomass as rotifer feed need further investigation. The present study aimed to investigate the potential application of $A$. platensis NIOF17/003, either as complete dry biomass (ACDB) or as lipid-free biomass (LFB), for the removal of ammonium ions $\left(\mathrm{NH}_{4}^{+}\right)$from aquaculture wastewater (under laboratorycontrolled conditions and using real aquaculture effluent). The effect of ACDB and LFB on the bacterial communities of the aquaculture effluent was evaluated. Furthermore, the application of ACDB and LFB, after saturation with nitrogen, as a feed for a marine rotifer, $B$. plicatilis, was examined.

\section{Materials and Methods}

\subsection{Arthrospira Strain}

In the current study, Arthrospira platensis NIOF17/003 (GenBank number: MW396472) was isolated (from a saline-alkaline lake, El-Khadra Lake, Wadi El-Natrun, Egypt), genetically identified, cultured under controlled conditions, and appreciated as a potential source for biodiesel production, as previously described by Zaki et al. [30]. Briefly, batch culture of A. platensis NIOF17/003 was cultivated for 2 weeks in $0.5 \mathrm{~L}$ of sterile Zarrouk culture medium [32], under constant controlled cultivation conditions of temperature $\left(28.5 \pm 1.5^{\circ} \mathrm{C}\right)$, illumination $\left(4000 \pm 500 \mathrm{Lux} \cdot 24 \mathrm{~h}^{-1}\right)$, and aseptic aeration, with shaking at $80 \mathrm{rpm}$ [30]. Biomass of $A$. platensis was harvested by centrifugation $\left(3000 \times \mathrm{g} \cdot 10 \mathrm{~min}^{-1}\right)$ on day 8 , which was the late exponential phase (LEP), to evaluate the biochemical composition, lipid profile, and physicochemical characteristics of the fatty acid methyl esters (FAMEs) identified and calculated according to the procedures reported by Zaki et al. [30]. Furthermore, the ACDW and LFB of A. platensis were individually dried for $48 \mathrm{~h}$ at $55^{\circ} \mathrm{C}$ and preserved in vacuum bags for further experiments.

\subsection{Adsorption Experiments}

\subsubsection{Adsorbent Preparation}

In the current study, ACDW and LFB were used as adsorbents for ammonium ions $\left(\mathrm{NH}_{4}{ }^{+}\right)$from aquaculture wastewater. Batch process ion exchange was achieved using flasks (100 $\mathrm{mL}$ of distilled water) in a shaker under different parameters of contact times $(15,30,45,60,120$, and $180 \mathrm{~min})$, initial ammonium ion concentrations (10, 20, 30, 40, 50 , and $\left.100 \mathrm{mg} \cdot \mathrm{L}^{-1}\right)$, and initial ammonium ion $\mathrm{pH}$ levels $(2,4,6,8$, and 10$)$ at various dosages $(0.02,0.04,0.06,0.08$, and $0.1 \mathrm{~g})$ of ACDW or LFB. The solution was shaken at $120 \mathrm{rpm}$ at room temperature $\left(25^{\circ} \mathrm{C}\right)$ at constant volume of solution. Ammonium ion concentrations were prepared using stock solution of ammonium chloride $\left(\mathrm{NH}_{4} \mathrm{Cl}\right)$ solution. The suspended solids and adsorbents were filtered, and the filtrate was analyzed according to APHA [33]. Water samples for ammonia $\left(\mathrm{NH}_{4}-\mathrm{N}\right)$ determination were placing in dark brown bottles as described by Koroleff in Grasshoff [34] and the reagents (1 mL of citrate solution $\left(480 \mathrm{~g} \cdot \mathrm{L}^{-1}\right), 1 \mathrm{~mL}$ of phenol reagent $\left(38 \mathrm{~g} \cdot \mathrm{L}^{-1}\right)$, and $1 \mathrm{~mL}$ of hypochlorite reagent $(5 \%)$ ) were added immediately to $35 \mathrm{~mL}$ of the sample in the field. The mixture was 
allowed to stand overnight (10-12 h), the blue color of indophenols formed was measured using a spectrophotometer at $630 \mathrm{~nm}$, and the results were expressed as $\mathrm{g} \cdot \mathrm{L}^{-1}$.

The removal percentage of $\mathrm{NH}_{4}{ }^{+}$and the amount of $\mathrm{NH}_{4}{ }^{+}$retained by ACDW and LFB were using by Equations (1) and (2), respectively [35].

$$
\begin{gathered}
\text { Removal percentage }(\%)=\frac{\left(C_{i}-C_{f}\right)}{C_{i}} \times 100, \\
\mathrm{q}_{e}=\frac{\left(C_{i}-C_{f}\right) \times V}{M},
\end{gathered}
$$

where $C_{i}\left(m g \cdot L^{-1}\right)$ represents the initial concentration, $C_{f}\left(m g \cdot L^{-1}\right)$ represents the equilibrium concentration, $\mathrm{V}(\mathrm{L})$ represents the total volume of ammonium, and $\mathrm{M}$ (grams) represents the weight of ACDW or LFB.

\subsubsection{Isotherm Studies}

Under laboratory conditions (temperature, $25^{\circ} \mathrm{C}$; contact time, $120 \mathrm{~min} ; \mathrm{pH}, 6$; $0.04 \mathrm{~g}$ of adsorbent (ACDW or LFB)), the adsorption isotherm study was applied. The Freundlich, Langmuir, and Halsey models were applied. The Freundlich model describes how the adsorbed ions are retained in many layers and is used to demonstrate heterogeneous systems and reversible sorption processes [36]. The Langmuir model predicts the presence of monolayer coverage of the sorbate at its external surface based on the assumption that intermolecular powers decrease rapidly with distance and predicts monolayer sorption on the external surface of the adsorbent compound [37]. However, the Halsey isotherm model is appropriate for multilayer adsorption and can be fitted to heteroporous substances [38]. Equations (3)-(5) and (7) are the mathematical equations of the Freundlich, Langmuir, and Halsey isotherm models, respectively.

$$
\begin{gathered}
\mathrm{q}_{\mathrm{e}}=\mathrm{K}_{\mathrm{f}} \mathrm{C}_{\mathrm{e}}^{1 / \mathrm{n}}, \\
\log \mathrm{q}_{\mathrm{e}}=\log \mathrm{K}_{\mathrm{f}}+\frac{1}{\mathrm{n}} \log \mathrm{C}_{\mathrm{e}^{\prime}}
\end{gathered}
$$

where $\mathrm{n}$ is the adsorption intensity, and $\mathrm{K}_{\mathrm{f}}$ is the Freundlich constant.

$$
\begin{gathered}
\mathrm{q}_{\mathrm{e}}=\frac{\mathrm{Q}_{\mathrm{m}} \mathrm{K}_{\mathrm{a}} \mathrm{C}_{\mathrm{e}}}{1+\mathrm{K}_{\mathrm{a}} \mathrm{C}_{\mathrm{e}}} \\
\frac{1}{\mathrm{Q}_{\mathrm{e}}}=\frac{1}{\mathrm{bq}_{\max }} \times \frac{1}{\mathrm{C}_{\mathrm{e}}}+\frac{1}{\mathrm{q}_{\max }},
\end{gathered}
$$

where $\mathrm{q}_{\mathrm{e}}$ is the adsorption capacity at equilibrium, $\mathrm{q}_{\max }$ is the maximum sorption capacity, and $\mathrm{b}$ is the Langmuir constant.

$$
\operatorname{Ln} \mathrm{q}_{\mathrm{e}}=\frac{1}{\mathrm{n}} \operatorname{Ln} \mathrm{K}+\frac{1}{\mathrm{n}} \operatorname{Ln} \mathrm{Ce},
$$

where $\mathrm{n}$ and $\mathrm{K}$ are Halsey constants.

\subsubsection{Kinetic Study}

Experiments were conducted in conical flasks at $\mathrm{pH} 6$ by mixing $0.1 \mathrm{~g}$ of adsorbents (ACDW or LFB) with $50 \mathrm{~mL}$ of an ammonia mixture of $10 \mathrm{mg} \cdot \mathrm{L}^{-1}$ concentration. The solution was stirred at room temperature for the required time intervals of $15,30,45,60$, 120 , and $180 \mathrm{~min}$.

\section{Pseudo-First-Order Kinetic Model}

The following equation is the linear form of the generalized pseudo-first-order equation [39]:

$$
D q / d_{t}=K_{1}\left(q_{e}-q_{t}\right),
$$


where $\mathrm{q}_{\mathrm{e}}$ is the amount of ammonia adsorbed at equilibrium $\left(\mathrm{mg} \cdot \mathrm{g}^{-1}\right), \mathrm{q}_{\mathrm{t}}$ denotes the amount of ammonia adsorbed at time $\mathrm{t}\left(\mathrm{mg} \cdot \mathrm{g}^{-1}\right)$, and $\mathrm{K}_{1}$ denotes the pseudo-first-order rate constant $\left(\mathrm{min}^{-1}\right)$.

The following criteria were used to evaluate the integrating equation:

$$
\log \left(\mathrm{q}_{\mathrm{e}} / \mathrm{q}_{\mathrm{e}}-\mathrm{q}_{\mathrm{t}}\right)=\mathrm{k}_{1} \mathrm{t} / 2.303,
$$

In a linear equation, the pseudo-first-order equation is provided by the following formula:

$$
\log \left(q_{e}-q_{t}\right)=\log q_{e}-k_{1} t / 2.303 .
$$

Plots of $\log \left(\mathrm{q}_{\mathrm{e}}-\mathrm{q}_{\mathrm{t}}\right)$ against $(\mathrm{t})$ should yield a linear relationship between $\mathrm{k} 1$ and $\mathrm{qe}$, which can be assessed using the slope and intercept, respectively.

Pseudo-Second-Order Kinetic Model

The pseudo-second order equation was expressed as the following form [40]:

$$
\mathrm{dq}_{\mathrm{t}} / \mathrm{d}_{\mathrm{t}}=\mathrm{K}_{2}\left(\mathrm{q}_{\mathrm{e}}-\mathrm{q}_{\mathrm{t}}\right)^{2}
$$

where $\mathrm{K}_{2}$ indicates the constant of second-order rate $\left(\mathrm{g} \cdot \mathrm{mg}^{-1} \cdot \mathrm{min}\right)$.

The integrating equation was as follows:

$$
1 /\left(\mathrm{q}_{\mathrm{e}}-\mathrm{q}_{\mathrm{t}}\right)=1 / \mathrm{q}_{\mathrm{e}}+\mathrm{K}_{2} .
$$

Ho et al. [41] obtained a linear form of the pseudo-second-order equation as follows:

$$
\mathrm{t} / \mathrm{q}_{\mathrm{t}}=1 / \mathrm{K}_{2} \mathrm{qe}^{2}+\mathrm{t} / \mathrm{qe}_{\mathrm{e}}
$$

Plots of $\left(t / q_{t}\right)$ against $(t)$ should yield a linear relationship, with the values of $q_{e}$ and $\mathrm{K}_{2}$ parameters calculated using the slope and intercept, respectively.

\subsubsection{Application of Aquaculture Wastewater}

A real aquaculture effluent sample was obtained from a private fish farm located in Alexandria ( $31^{\circ} 12^{\prime} 30.07^{\prime \prime} \mathrm{N}$ and $29^{\circ} 58^{\prime} 41.66^{\prime \prime} \mathrm{E}$ ), Egypt. The aquacultured fish species was Nile tilapia, Oreochromis niloticus. The physicochemical parameters of effluent sample of $\mathrm{pH}$ (8.7), total suspended solids (TSS, $211 \mathrm{mg} \cdot \mathrm{L}^{-1}$ ), total dissolved solids (TDS, $\left.3110 \mathrm{mg} \cdot \mathrm{L}^{-1}\right)$, and ammonium ions $\left(\mathrm{NH}_{4}{ }^{+}, 13.93 \mu \mathrm{g} \cdot \mathrm{L}^{-1}\right)$ were determined. ACDW and LFB were used to remove ammonia from aquaculture wastewater effluent under the ideal conditions of $\mathrm{pH} 8$ for $120 \mathrm{~min}$ (contact time) and $0.1 \mathrm{~g}$ of ACDW and LFB (adsorbents). As the ammonia concentration was low in the aquaculture effluent sample, a volume of ammonia solution was added to a final concentration of $10 \mathrm{mg} \cdot \mathrm{L}^{-1}$, depending on the results obtained from laboratory conditions. To remove precipitates and suspended matter, the solution was filtered. To quantify the effect of adsorbent on ammonia removal, deionized water with a similar concentration of ammonia was prepared as a control.

\subsubsection{Adsorbent Characterization}

To evaluate the morphological features of ACDW and LFB before and after ammonia removal, scanning electron microscopy (SEM), Fourier-transform infrared (FTIR) spectroscopy, and Raman analytical spectrophotometry were employed using a JSM-IT200 SEM microscope, a Bruker Model Vertex 70 FTIR spectrometer connected to a platinum ATR unit, Bruker, Germany, and a Bruker Senterra Raman spectrometer (USA), respectively. 


\subsection{Influence of Adsorbents on the Bacterial Count}

The effects of adsorbents (ACDW and LFB) on the structure of the bacterial communities in real aquaculture wastewater effluent after ammonia removal were examined. According to Yahaya et al. [42], the bacterial count was examined in five treatments (samples): (1) filtered lipid-free biomass (LFB), (2) aquaculture wastewater treated with LFB (LFB-RAW), (3) filtered complete dry biomass (ACDW), (4) aquaculture wastewater treated with ACDW (ACDW-RAW), and (5) an aquaculture wastewater (RAW) sample that was not treated with $A$. platensis as a control. Sterile nutrient agar media was prepared by autoclaving at $120^{\circ} \mathrm{C}$ for $20 \mathrm{~min} ; 1 \mathrm{~g} \cdot \mathrm{mL}^{-1}$ of each sample was inoculated using pouring technique. Diffusion was allowed to occur in cultured plates for $2 \mathrm{~h}$ at room temperature. The plates were incubated in an upright position at $37^{\circ} \mathrm{C}$ for $48 \mathrm{~h}$. For each treatment, the bacterial colonies were counted (CFU) and estimated using the following formula:

$$
\mathrm{CFU}=\text { number of colonies } \times \text { dilution factor/sample volume }(\mathrm{mL}) \text {. }
$$

\subsection{Bioassay Test}

In the current study, the influence of different concentrations $(0.02,0.05,0.10$, and $0.20 \mathrm{~g}$ ) of ACDB and LFB loaded with ammonia, compared to the same concentrations without ammonia loading (as a control), on rotifer (Brachionus plicatilis, L-type, $180 \mu \mathrm{m}$ ) population, mortality, and females carrying eggs (population and mortality) were investigated. Before the experiment, rotifers were mass produced in culture tanks under controlled culture conditions of temperature $\left(23^{\circ} \mathrm{C}\right)$, salinity ( $\left.30 \mathrm{ppt}\right)$, and $\mathrm{pH}(7.5)$, using continuous aeration and supplemented with the previously identified marine microalga Nannochloropsis oceanica NIOF15/001 [43] at concentration level of $5.5 \times 10^{6}$ cells $\cdot \mathrm{mL}^{-1} \cdot$ day $^{-1}$. To begin the experiment, B. plicatilis was taken from the culture tanks and starved for $24 \mathrm{~h}$ to allow total gut discharge before being placed into plastic jars supplied with $500 \mathrm{~mL}$ of filtered saltwater, with three replicates per level. This trial was performed for $72 \mathrm{~h}$ in the following conditions: temperature $\left(23^{\circ} \mathrm{C}\right)$, salinity $(30 \mathrm{ppt})$, and $\mathrm{pH}(7.5)$, without aeration [31]. Tested rotifer parameters of population growth, population mortality, and population and mortality of females carrying eggs were investigated as described previously by Alprol et al. [31]. The population growth was calculated as the increase/decrease in B. plicatilis individual number, which was at an initial stocking density of $16,500 \pm 540$ individuals. $\mathrm{L}^{-1}$. The eggcarrying population of $B$. plicatilis was estimated as the number of females carrying eggs, which was at an initial stocking density of $14,000 \pm 500 \mathrm{females} \cdot \mathrm{L}^{-1}$. On the other hand, the total mortality of B. plicatilis (individuals $\cdot \mathrm{L}^{-1}$ ) and the total mortality of females carrying eggs (females. $\mathrm{L}^{-1}$ ) were calculated as the dead organisms and females, respectively, by investigations of samples under optical microscope using a Sedgwick-Rafter counting cell as described previously [30,31].

\subsection{Chemicals}

The following reagents were used: ethylenediaminetetraacetic acid (EDTA) $\left(\mathrm{C}_{10} \mathrm{H}_{16} \mathrm{~N}_{2} \mathrm{O}_{8}\right)$, zinc sulfate $\left(\mathrm{ZnSO}_{4} \cdot 7 \mathrm{H}_{2} \mathrm{O}\right)$, citrate solution, phenol reagent, hypochlorite reagent, and ammonium chloride $\left(\mathrm{NH}_{4} \mathrm{Cl}\right)$. Solution $\mathrm{pH}$ was adjusted with dilute $\mathrm{NH}_{3}$ and $\mathrm{HNO}_{3}$.

\subsection{Statistical Analysis}

Before performing the statistical analysis, the uncertainties of symmetric, normal, and endogenous data (mean $\pm \mathrm{SD}, n=3$ ) were ascertained. Statistical analyses were applied using SPSS program (IBM, v. 20, Armonk, NY, USA). All evaluated variables were performed at a significant level $(p<0.05)$, to a study ANOVA, followed by Duncan's multiple range examinations and then least significant difference (LSD) tests. 


\section{Results and Discussion}

\subsection{Characterization of Adsorbents}

\subsubsection{FTIR Analysis}

Figure 1 illustrates the IR spectra of ACDW and LFB before and after adsorption of ammonia, showing broad and strong absorption peaks at $3268-3877 \mathrm{~cm}^{-1}$ (intense and broad band) attributed to the stretching vibration of $\mathrm{N}-\mathrm{H}$ and $\mathrm{O}-\mathrm{H}$ groups [44]. The bands observed after adsorption at $2917-2926 \mathrm{~cm}^{-1}$ for ACDW and LFB indicate the stretching vibrations of asymmetric $\mathrm{C}-\mathrm{H}$ bonds of methyl, methylene, and methoxy groups [45]. Furthermore, the presence of new peaks around 2352.58 and $2322.90 \mathrm{~cm}^{-1}$ for ACDW and LFB might have been due to the presence of amide. Moreover, the absorption new peaks at $2195.09 \mathrm{~cm}^{-1}$ for ACDW indicated the presence of $\mathrm{C} \equiv \mathrm{N}$. The new peak after adsorption for ACWD at $2068.30 \mathrm{~cm}^{-1}$ was tentatively assigned to $(C \equiv C)$ stretching. The absorbance band at 1635.36 and $1632.28 \mathrm{~cm}^{-1}$ (before and after adsorption for ACWD), as well as the peaks at 1628.75 and $1626.77 \mathrm{~cm}^{-1}$ (before and after adsorption for LFB), could be ascribed to the existence of carbonyl $\mathrm{C}=\mathrm{O}$ stretching of the carboxyl groups and aromatic $\mathrm{C}=\mathrm{C}$ ring stretching. Furthermore, $\mathrm{NH}_{2}$ group bending was indicated at 1632 and $1626 \mathrm{~cm}^{-1}$ for ACDW and LFB, respectively [46]. The intense band seen at $1527-1532 \mathrm{~cm}^{-1}$ indicated the presence of $\mathrm{N}-\mathrm{H}$ bending and $\mathrm{C}=\mathrm{C}$ stretching, which might be attributed to the presence of aromatics. Moreover, there were numerous shoulders and small bands in the scope of the region between 1449.22 and $1233.89 \mathrm{~cm}^{-1}$ which were assigned to the aromatic rings, $\mathrm{C}-\mathrm{O}$ stretching absorption peaks, and $\mathrm{C}-\mathrm{H}$ bending vibration [47]. Furthermore the signal around 1391-1397 $\mathrm{cm}^{-1}$ may have been due to sulfate [45]. The observed peaks at 1032.15 and $1029.56 \mathrm{~cm}^{-1}$ before adsorption shifted to around 1439 and $1042.99 \mathrm{~cm}^{-1}$ after adsorption of ACDW and LFB, respectively, confirming the presence of $\mathrm{C}-\mathrm{O}$ stretching. Additionally, the peaks around 448.73 and $457.77 \mathrm{~cm}^{-1}$ (before adsorption of ACDW and $\mathrm{LFB}$, respectively) were created by the stretching of $\mathrm{C}-\mathrm{H}$. Based on FTIR examination, the creation of new peaks, the alteration in absorption intensity, the disappearance of some peaks, and the shift in wavenumber of functional groups might be attributed to the relationships of different ions with active sites of the biomass. Furthermore, interactions of ammonium ions were expected to occur with $\mathrm{NH}_{2}, \mathrm{C}=\mathrm{O}, \mathrm{COO}$, and $\mathrm{OH}$ groups on the aromatic groups in the adsorbents [46].

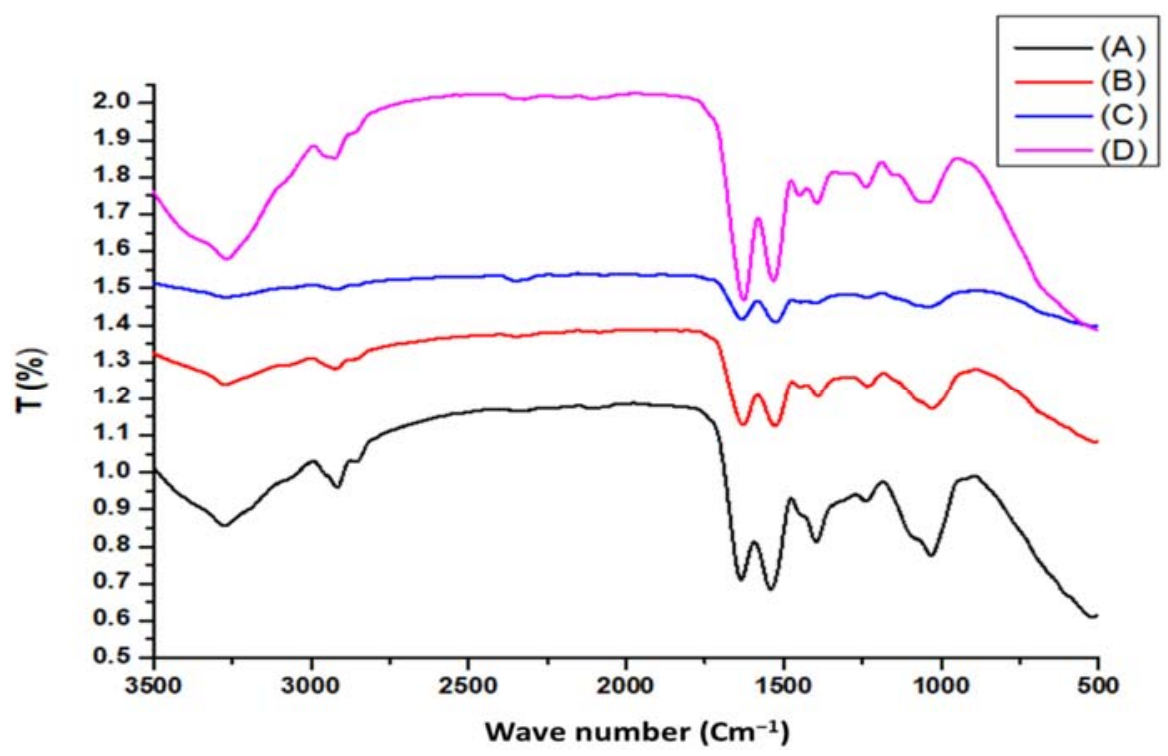

Figure 1. FTIR spectra for (A) ACDW before treatment, (B) ACDW after treatment, (C) LFB before adsorption, and (D) LFB after adsorption of ammonia. 


\subsubsection{Raman Spectral Analysis}

Figure 2 shows the vibrational data of the symmetry of chemical bonds and molecules which could be recognized from Raman spectroscopy analysis compositions of $A$. platensis (ACDW and LFB before and after adsorption). Each type of biomolecule was shown to have its own characteristic signature Raman spectrum. The band at $3361 \mathrm{~cm}^{-1}$ was ascribed to the $\mathrm{N}-\mathrm{H}$ stretching, while the absorption peaks at $3640-4181 \mathrm{~cm}^{-1}$ were attributed to $v(\mathrm{O}-\mathrm{H})$. The peaks at $1820-1893 \mathrm{~cm}^{-1}$ were related to the skeletal vibrations of $\mathrm{C}=\mathrm{C}$ stretching mode. Furthermore, the absorption peaks at $1751-1764 \mathrm{~cm}^{-1}$ were representative of the $\mathrm{C}=\mathrm{O}$ groups in carboxyl and carbonyl moieties. The absorption peaks at 1641 and $1639 \mathrm{~cm}^{-1}$ were ascribed to the $\delta\left(\mathrm{H}_{2} \mathrm{O}\right)$ and $\mathrm{C}=\mathrm{N}$ vibration groups (the $\mathrm{G}$ band refers to the first-order scattering of the $\mathrm{E}_{2 \mathrm{~g}}$ phonon of $s p^{2} \mathrm{C}$ molecules), while the peak at $1415.75 \mathrm{~cm}^{-1}$ for ACWD corresponded to $\delta\left(\mathrm{CH}_{2}\right)$ and $\delta\left(\mathrm{CH}_{3}\right)$. The bands at 1004 and $1105 \mathrm{~cm}^{-1}$ were ascribed to $v(C=S)$. The new absorption peaks at 809 and $901.83 \mathrm{~cm}^{-1}$ were representative of $v(\mathrm{C}-\mathrm{O}-\mathrm{C})$. The disappearance and formation of new peaks of the vibration bands of the adsorbents are presented in Figure 2.

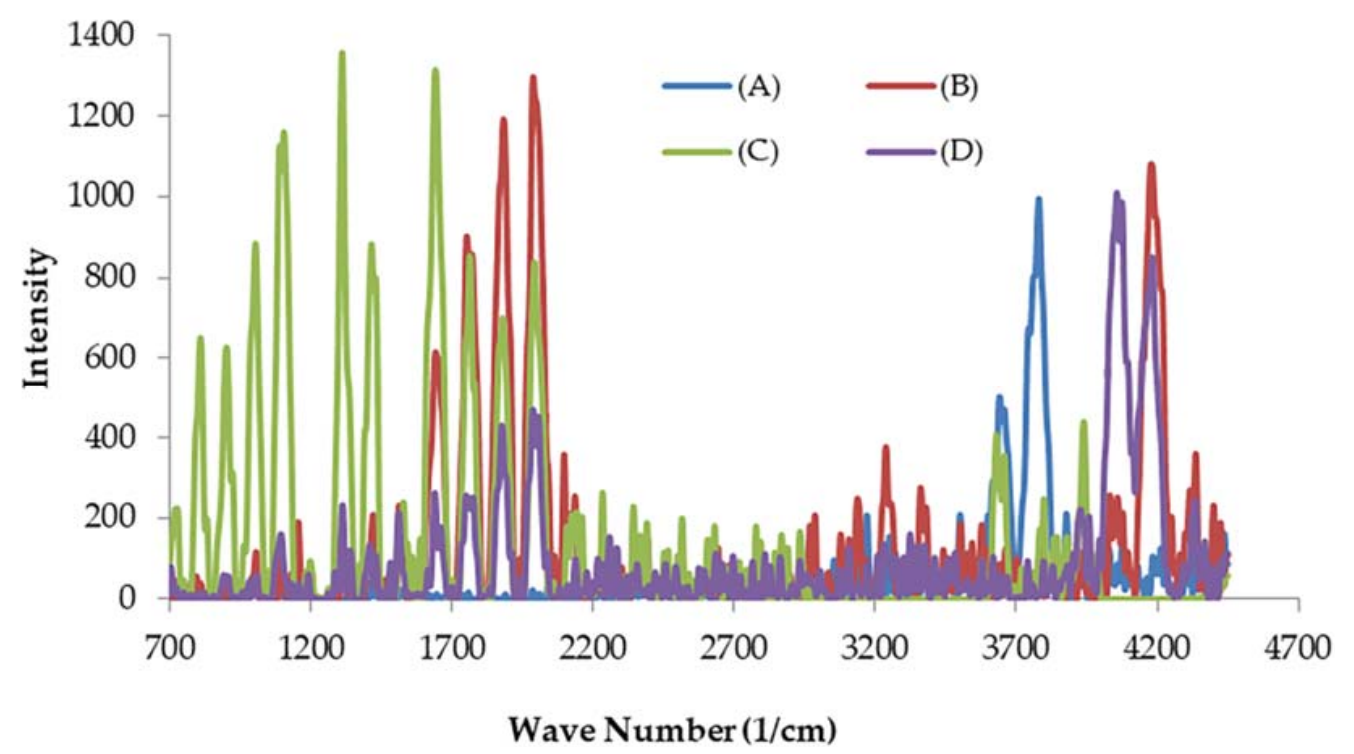

Figure 2. Raman spectrum for spectra for (A) ACDW before treatment, (B) ACDW after treatment, (C) LFB before treatment, and (D) LFB after treatment of ammonia.

\subsubsection{Scanning Electron Microscopy}

The morphology of ACDW and LFB before and after ammonia uptake is shown in Figure 3. Figure 3A displays the SEM micrograph of ACDW before exposure to ammonia [31]; the cells formed agglomerates and had certain dimensions, with the existence of tiny macropores of different size at the external biomass surface. However, mineral substance could be shown within a conical shape with small pieces and irregular surface texture of the ACDW after adsorption of ammonia (Figure 3B). The morphology of ACDW after adsorption of ammonia was in the form of a helical tube of different sizes. Furthermore, the image showed the random distribution of highly porous regions, as presented in Figure 3B. Figure 3C displays the SEM image of LFB before adsorption, which showed a colonized surface with a homogeneous distribution, and the particles had certain dimensions [31]. However, mineral substance could be shown within a conical shape with small pieces and irregular surface texture of the LFB after adsorption of ammonia (Figure 3D). On the other hand, the mean diameter of ACDW before treatment of ammonia was $194.97 \mathrm{~nm}$, but the average diameter ACDW after adsorption was $128.96 \mathrm{~nm}$. The average diameter distribution of LFB before and after ammonia treatment was 176.09 and $144.16 \mathrm{~nm}$, respectively. 


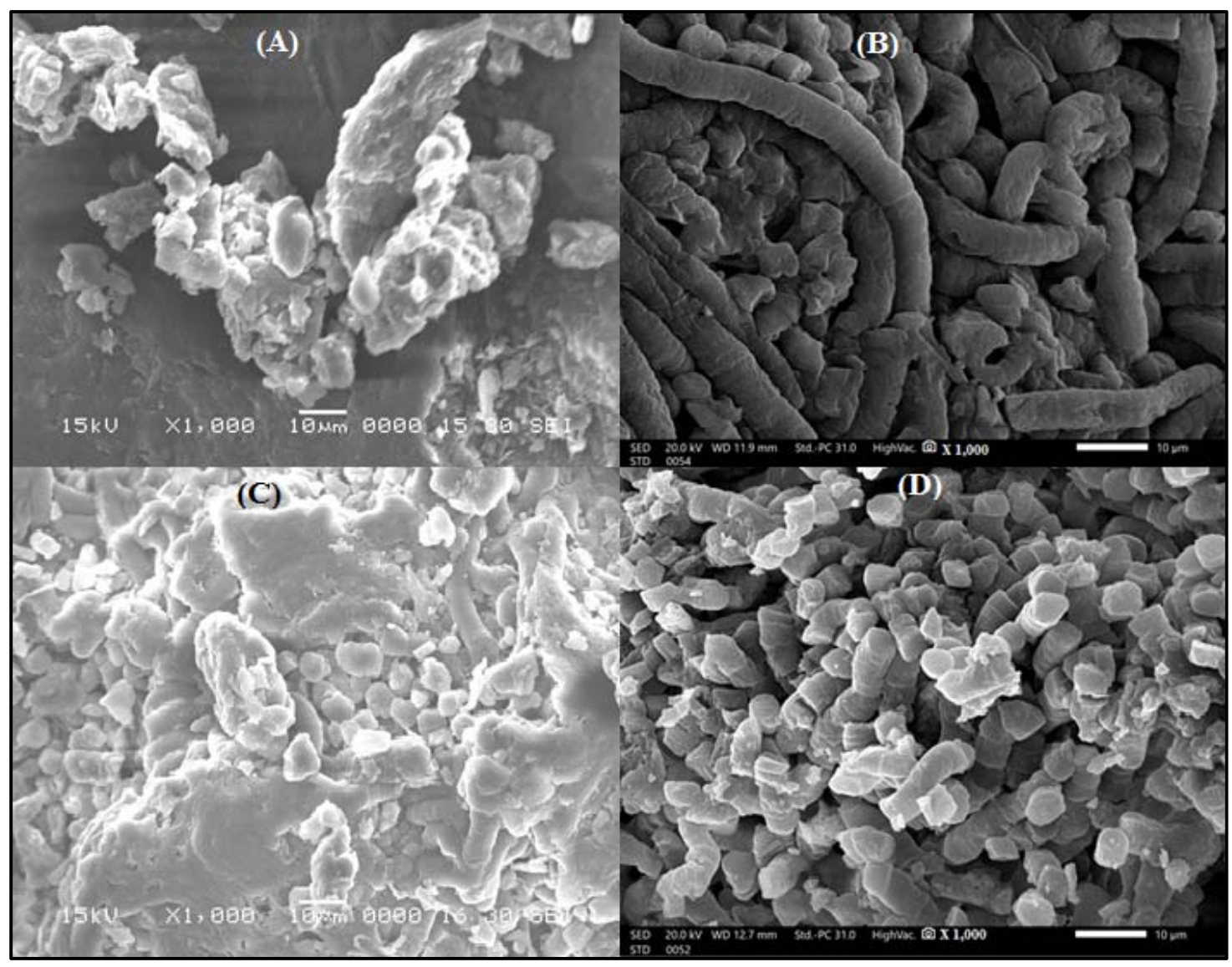

Figure 3. SEM pictures of ACDW before adsorption (A), ACDW after adsorption (B) and LFB before adsorption (C), and LFB after adsorption (D).

\subsection{Adsorption Studies}

\subsubsection{Influence of $\mathrm{pH}$}

The $\mathrm{pH}$ plays a significant role in numerous cellular processes related to structure, energy metabolism, organelle function, enzymes, and proteins. The $\mathrm{pH}$ value affects the external charge of the adsorbents $[48,49]$. The adsorption of ammonia $\left(\mathrm{NH}_{4}^{+}\right)$by two natural adsorbents of ACDW and LFB was examined at $\mathrm{pH}$ values of 2, 4, 6, 8, and 10 (Figure 4), while keeping the other parameters constant. The temperature of the solution, the volume of the solution, the amount of adsorbent used, the initial ammonia concentration, and the shaking period were $25^{\circ} \mathrm{C}, 10 \mathrm{~mL}, 0.04 \mathrm{~g}, 30 \mathrm{mg} \cdot \mathrm{L}^{-1}$, and $120 \mathrm{~min}$, respectively. The obtained results indicated that the adsorption process of ammonia was favorable in acidic medium for LFB and alkaline medium for ACDW. It was found that the percentage of $\mathrm{NH}_{4}$ removal reached a maximum value at $\mathrm{pH} 6$ with $63.3 \%$ and $67.8 \%$ for ACDW and FLB of dried microalgae, respectively, after which the percentage removal decreased slightly.

In the aquatic environment, ammonia volatile particles are considered to have a high solubility, because they simply exist in aquatic solutions. In aquaculture, the sum of the ionized form $\left(\mathrm{NH}_{4}{ }^{+}\right)$and unionized form $\left(\mathrm{NH}_{3}\right)$ of nitrogen creates a buffer system of ammonium/ammonia. This equilibrium is based on the $\mathrm{pH}$ [28]. When the $\mathrm{pH}$ is less than 9.25, hydrogen ions are combined into ammonia to create ammonium ions, becoming the main species in the solution [10]. Therefore, as $\mathrm{pH}$ increases, the ammonia concentration rises. In natural waters, ammonium ions exist in greater concentrations than ammonia because of the prevalence of neutral $\mathrm{pH}$. Hence, ammonia is characterized as the most poisonous $\mathrm{N}$ form, having a direct influence on the photosynthetic process of microalgal biomass [23]. Peterson et al. [50] showed that the active groups on the algae surface produce 
negative charges in acidic $\mathrm{pH}$ conditions, generating electrostatic interfaces across the cell surface and cationic species, which are responsible for adsorption.

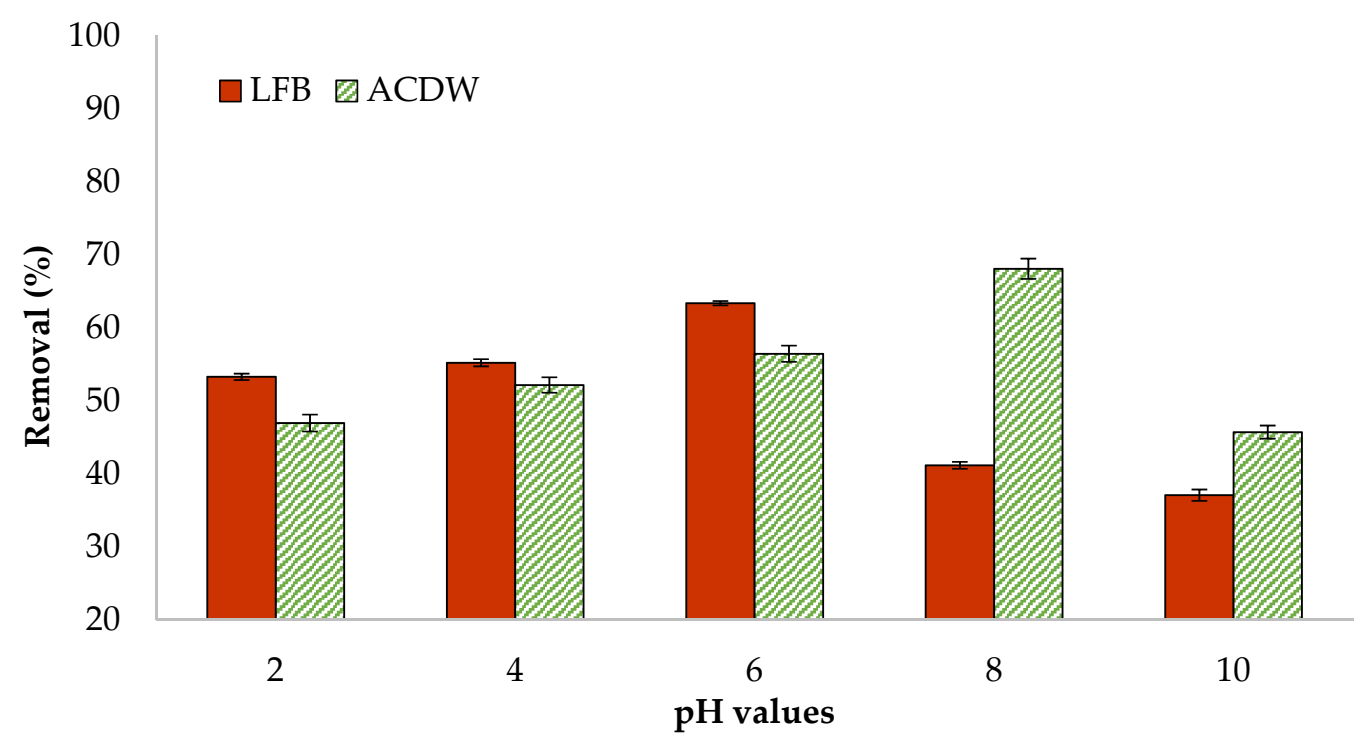

Figure 4. Influence of $\mathrm{pH}$ value on the adsorption of ammonia using whole biomass (ACDW) and lipid-free biomass (LFB) of Arthrospira platensis.

\subsubsection{Influence of Contact Time}

Contact time is inevitably a fundamental factor in all transfer phenomena such as adsorption, and the equilibrium time is one of the significant concerns for economical wastewater treatment [51]. The effect of contact time on the adsorption of $\mathrm{NH}_{4}$ by algae was evaluated in $0.04 \mathrm{~g}$ of adsorbent and $10 \mathrm{~mL}$ of $30 \mathrm{mg} \cdot \mathrm{L}^{-1} \mathrm{NH}_{4}$ solution, with a solution $\mathrm{pH}$ of 8 at $25{ }^{\circ} \mathrm{C}$. The adsorption of $\mathrm{NH}_{4}$ by LFB from aqueous solution exhibited that the percentage removal increased to $63.95 \%$ with an increase in contact time. The uptake of $\mathrm{NH}_{4}$ by ACDW showed that most of the removal happened in the first 15 min of contact time $(71.5 \%)$ (Figure 5).

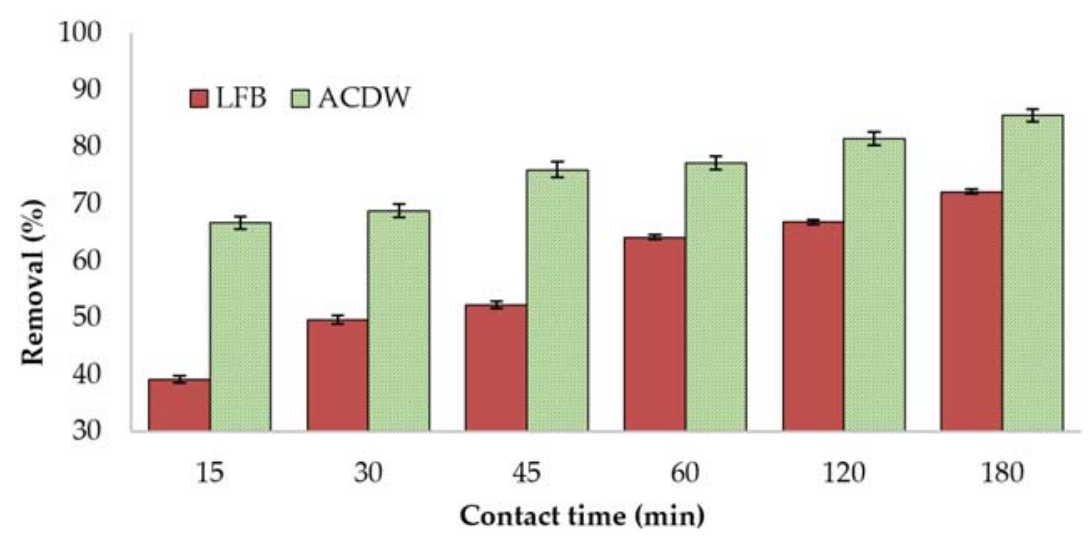

Figure 5. Influence of contact time on the treatment of ammonia using whole biomass (ACDW) and lipid-free biomass (LFB) of Arthrospira platensis.

This augmentation could be attributed to the effect of the alteration in $\mathrm{pH}$ and stirring resulting from the addition of adsorbents [8]. The adsorption occurred in two steps. Initially, ions of ammonia were passively adsorbed onto the cell membranes of algae, where the sorption process was very fast because of an excessive number of vacant external sites. In the second step, sorption rates declined and eventually reached equilibrium due to the decrease in available sites, which were not easily occupied as a result of the repulsive powers among the solute particles adsorbed onto the bulk phase and the solid surface [36]. 


\subsubsection{Influence of the Adsorbent Dosage}

The influence of ACDW and LFB was examined at $25^{\circ} \mathrm{C}$ by varying the sorbent amounts from 0.02 to $0.1 \mathrm{~g}$. For each of these runs, the concentration of ammonia was set to $30 \mathrm{mg} \cdot \mathrm{L}^{-1}$, with $10 \mathrm{~mL}$ of $30 \mathrm{mg} \cdot \mathrm{L}^{-1} \mathrm{NH}_{4}$ solution having a $\mathrm{pH}$ of 8 for $120 \mathrm{~min}$, and the results are demonstrated in Figure 6. The obtained results showed that the sorption of ammonia increased gradually with an increase in the quantity of ACDW or LFB from $0.02 \mathrm{~g}$ to $0.1 \mathrm{~g}$, owing to the higher obtainability of binding sites of the surface area and a stronger driving force of ACDW and LFB [37].

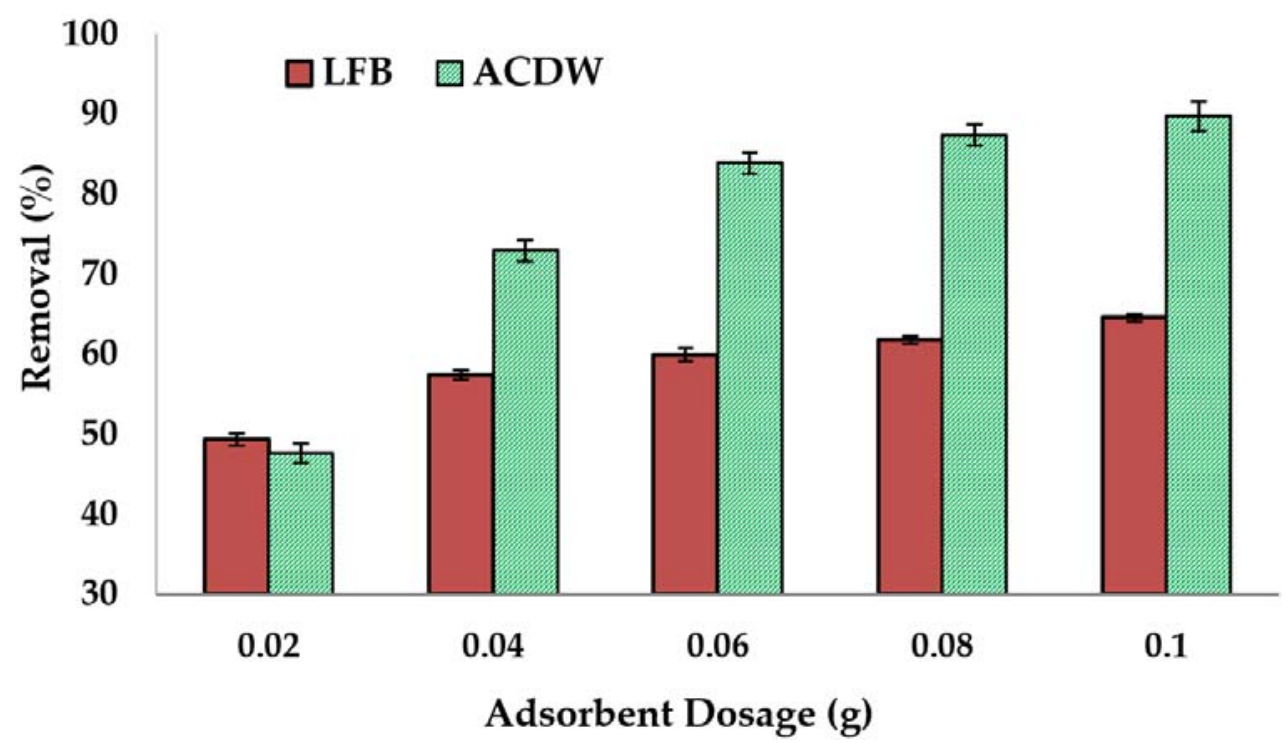

Figure 6. Influence of adsorbent dosage on the treatment of ammonia using whole biomass (ACDW) and lipid-free biomass (LFB) of Arthrospira platensis.

\subsubsection{Influence of Initial $\mathrm{NH}_{4}{ }^{+}$Concentration}

In order to assess this influence, sorption experiments were performed at the initial $\mathrm{NH}_{4}{ }^{+}$concentrations of $10,20,30,40,50$, and $100 \mathrm{mg} \cdot \mathrm{L}^{-1}$ at $\mathrm{pH} 8$ with $0.04 \mathrm{~g}$ of adsorbent added to $10 \mathrm{~mL}$ solutions at $25^{\circ} \mathrm{C}$.

The present study showed that the maximum uptake of $\mathrm{NH}_{4}{ }^{+}$was recorded at the concentration $10 \mathrm{mg} \cdot \mathrm{L}^{-1}$, as demonstrated in Figure 7 . At higher concentrations, the adsorption slightly decreased until the end of the tests at the same contact time and adsorption temperature. This phenomenon could be explained by the greatest number of existing adsorption sites of ACDW and LFB of dried A. platensis, which led to fast equilibrium and diffusion. Ion exchange takes place at the pores of the adsorbent material and its internal surface when the outside surface is saturated [52]. Furthermore, the ratio of $\mathrm{NH}_{4}{ }^{+}$ions to active sites was small at low initial concentrations. In contrast, this ratio relatively increased at high initial $\mathrm{NH}_{4}{ }^{+}$concentrations, where the number of $\mathrm{NH}_{4}{ }^{+}$ ions was greater than the number of active sites obtainable for sorption, which became exhausted owing to competition for actives sites. Therefore, a fast initial uptake of $\mathrm{NH}_{4}^{+}$ ions occurred at the initial stage of adsorption process [53], showing a reduction in the removal efficiency at elevated ion concentrations. 


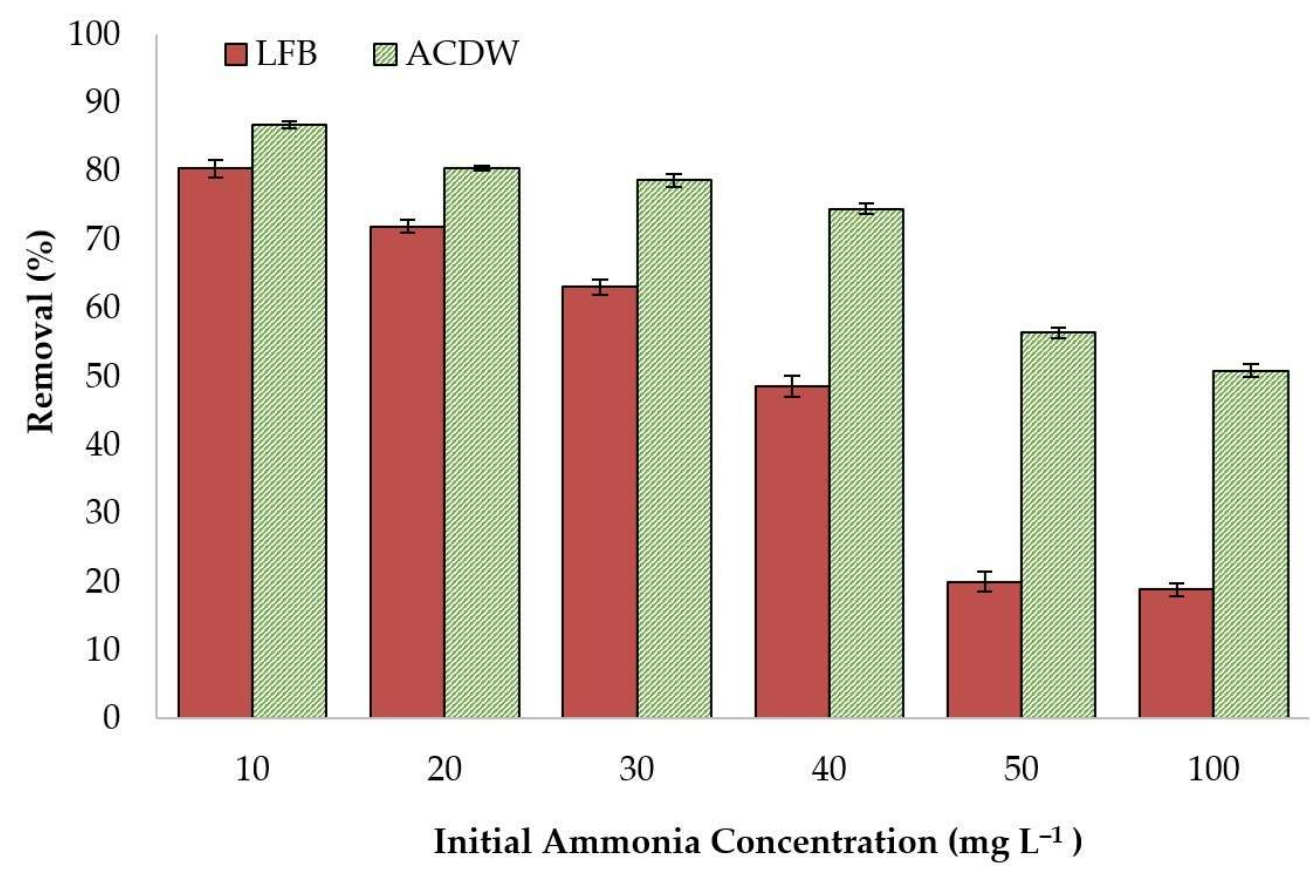

Figure 7. Influence of initial ammonia concentration on the treatment of ammonia using whole biomass (ACDW) and lipid-free biomass (LFB) of Arthrospira platensis.

\subsection{Applicability to Real Aquaculture Wastewater}

Due to the large dimensions of Arthrospira, the separation of Arthrospira biomass (either ACDW or LFB) from the water column can be easily performed by filtering the water using a phytoplankton net (screen) with a mesh size of a $60 \mu \mathrm{m}$ [54]. Many previous studies utilized microalgae as a bioremediation source for treating aquaculture wastewater such as Chlorella vulgaris, Chlorococcum sp., Parachlorella kessleri, Scenedesmus quadricauda, Scenedesmus obliquus [55], and Arthrospira platensis [24,56]. However, all previous studies cultivated living microalgae in the aquaculture wastewater. However, the present study is the first to use the complete dried biomass (ACDW) or lipid-free biomass (LFB) of Arthrospira platensis to remove ammonia from aquaculture wastewater. The results obtained showed that approximately $25.7 \%$ and $37.8 \%$ of ammonium ions were removed from aquaculture wastewater by $\mathrm{ACDW}$ and $\mathrm{LFB}$, respectively. In contrast, the percentage of ammonium ion removal from synthetic aqueous solution achieved through dilution in distilled water with $\mathrm{NH}_{4} \mathrm{Cl}$ was $64.24 \%$ and $89.68 \%$ for ACDW and LFB, respectively (Table 1). The obtained results confirmed that the removal of ammonium ions by the two used adsorbents was affected by the real aquaculture wastewater. The effluents used in this work contain high concentrations of mixed effluents as pollutants resulting from pond effluents of Nile tilapia aquaculture wastewater, which resulted in competition with ammonia ions at the active sites, leading to lower removal efficiency. Different inorganic nitrogen types in wastewater can be converted to organic nitrogen by microalgae. Previous research has shown that nitrification or denitrification, as well as biological nitrogen uptake by distributed biomass, are the main mechanisms for nitrogen removal in algal systems [56-58]. Carbohydrates and polysaccharides in microalgal cell walls may contain several negatively charged (amino, hydroxyl, carboxyl, pyruvate, sulfide, phosphate, etc.) groups that act as active sites for adsorbing positively charged metal cations. Heavy metals could potentially be transferred into cells via the cell membrane, lowering their quantities in effluent [59]. Exopolysaccharides, commonly known as exopolysaccharides, are polysaccharides released by microalgae into the growth media [60]. Exopolysaccharide molecules with negatively charged groups can also absorb metals [61]. There are three main mechanisms (biodegradation, adsorption, consumption) that microalgae utilize to eliminate organics from wastewater. Microalgal cell walls feature numerous polymer 
groups that offer potential sorption sites for organic pollutants; however, the removal of organics by microalgal sorption was found to be rather low [62].

Table 1. Treatment for ammonium ions using ASDW and LFB in different water samples.

\begin{tabular}{ccc}
\hline \multirow{2}{*}{ Types of Water } & \multicolumn{2}{c}{ Ammonium Ions Removal (\%) } \\
\cline { 2 - 3 } & ACDW & LFB \\
\hline Synthetic aqueous solution & 64.24 & 89.68 \\
\hline Real aquaculture effluent & 25.70 & 37.80 \\
\hline
\end{tabular}

\subsection{Isothermal Analysis}

The obtained data in Figures 8-10 agreed with the experimental results of Freundlich isotherm model, as confirmed by the high linear correlation coefficient $\left(R^{2}=0.914\right.$ and 0.987 for ACDW and LFB, respectively), indicating that this model is favorable for physical adsorption. A strong bond occurred between $\mathrm{NH}_{4}{ }^{+}$and the adsorbent, as shown by the value of $1 / \mathrm{n}$, known as the heterogeneity factor. The deviation from sorption linearity is described as follows: if $1 / \mathrm{n}$ equals 1 , the adsorption is linear, and the concentration of ammonia particles has no effect on the division between the two stages; when $1 / \mathrm{n}$ is less than 1 , chemical adsorption occurs, resulting in a typical Langmuir isotherm (Table 2); when $1 / \mathrm{n}$ is greater than 1 , cooperative adsorption occurs, resulting in an unusual Langmuir isotherm [51]. The values of factor " $1 / \mathrm{n}$ " in this study were higher than one, indicating that a physical adsorption method on an external surface using this isotherm equation is preferable. When the Langmuir isotherm was applied, the obtained results agreed with the experimental data with high correlation coefficients $\left(R^{2}=0.937\right.$ and 0.985 for ACDW and LFB, respectively). The equilibrium sorption $\left(\mathrm{q}_{\mathrm{e}}\right)$ increased with the rise in ammonia concentration. Many investigational models following a Langmuir equation include monolayer coverage. Furthermore, the Halsey isotherm model (Table 2) was not compatible with the adsorption technique, as the correlation coefficient $\left(R^{2}\right)$ was less than 0.900 for ACDW and LFB.

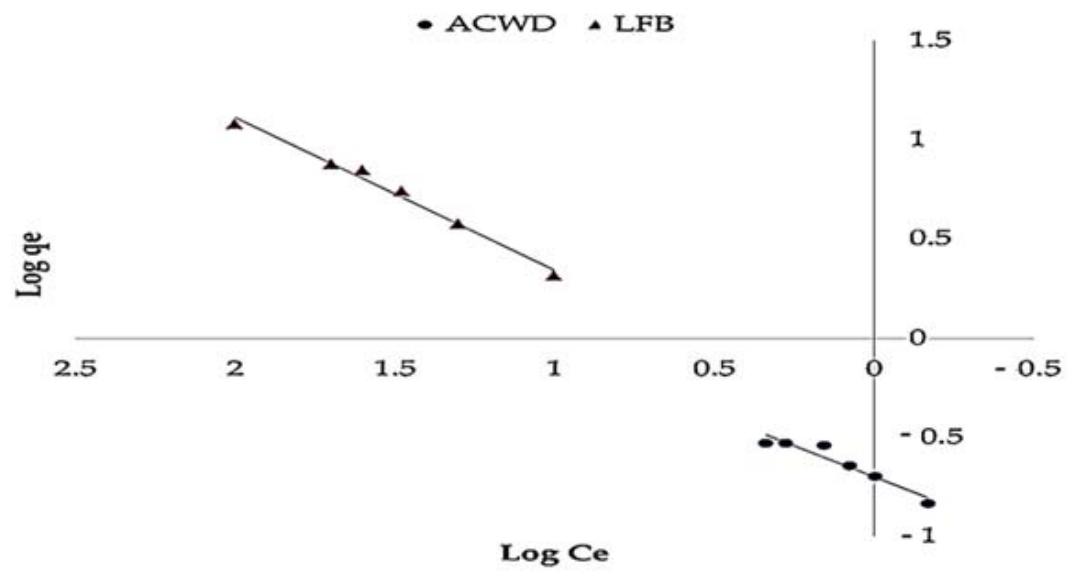

Figure 8. Freundlich isotherm plot for the sorption of ammonia using whole biomass (ACDW) and lipid-free biomass (LFB) of Arthrospira platensis. 


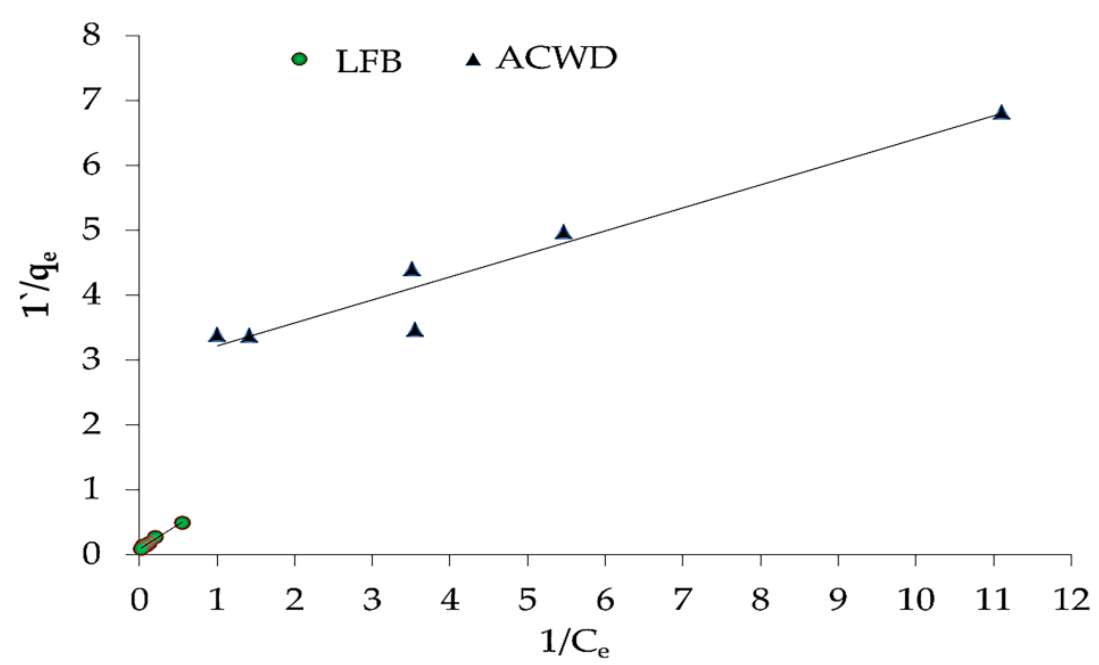

Figure 9. Langmuir isotherm plot for the sorption of ammonia using whole biomass (ACDW) and lipid-free biomass (LFB) of Arthrospira platensis.

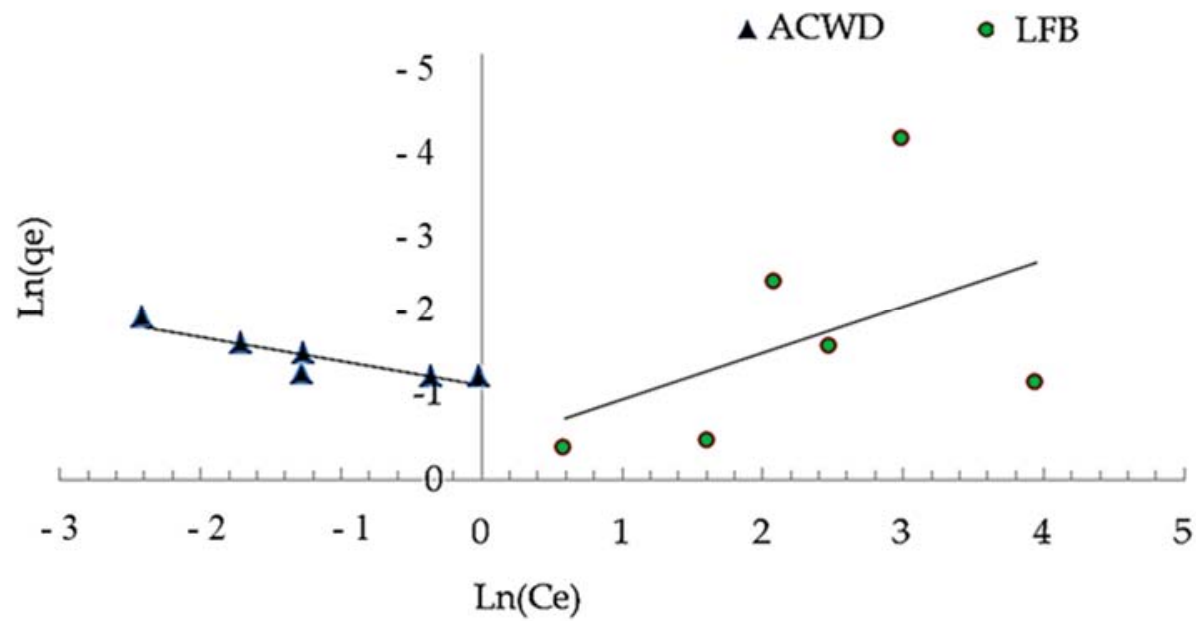

Figure 10. Halsey model plot for the sorption of ammonia using whole biomass (ACDW) and lipid-free biomass (LFB) of Arthrospira platensis.

Table 2. Isotherm factor of ammonium ion adsorptions (ACDW and LFB).

\begin{tabular}{cccc}
\hline Isotherm Models & Parameters & ACDW & LFB \\
\hline \multirow{3}{*}{ Freundlich Model } & $R^{2}$ & 0.914 & 0.987 \\
& $1 / \mathrm{n}$ & 1.463 & 1.279 \\
& $\mathrm{~K}_{\mathrm{f}}$ & 10.73 & 3.16 \\
\hline \multirow{2}{*}{ Langmuir Model } & $R^{2}$ & 0.937 & 0.985 \\
& $\mathrm{q}_{\max }\left(\mathrm{mg}^{-} \mathrm{g}^{-1}\right)$ & 0.379 & 0.745 \\
\hline \multirow{2}{*}{ Halsey Model } & $R^{2}$ & 0.884 & 0.213 \\
& $1 / \mathrm{n}_{\mathrm{H}}$ & 2.797 & 0.390 \\
& $\mathrm{~K}_{\mathrm{H}}$ & 2.884 & 1.64 \\
\hline
\end{tabular}

\subsection{Kinetic Analysis}

The kinetics of adsorbate uptake is critical for selecting the best operating conditions for design [49]. The kinetic data obtained from the adsorption of ammonium ions onto ACWD and LFB adsorbents was studied using the pseudo-first- and pseudo-secondorder kinetic models. The kinetic parameters of ammonium ions are presented in Table 3. The linear correlation coefficients $R^{2}$ in the obtained data were not close to 1 , implying that the pseudo-first-order (PFO) equation was not appropriate for exposing the reaction 
mechanism of ammonium ions with the adsorbents. In contrast, it can be seen that the pseudo-second-order (PSO) kinetic equations fitted considerably well with the investigational data, as shown in Table 3. The correlation coefficient values were close to one, indicating good agreement $\left(R^{2}=0.999\right.$ and 0.996 for ACDW and LFB, respectively). Furthermore, the anticipated ( $\mathrm{q}_{\mathrm{e}}$ calculation) values were close to the experimental ones ( $\mathrm{q}_{\mathrm{e}}$ experimental). Thus, the PSO equation corresponded well to the ammonium ion adsorption method exhibited by ACDW and LFB (Figure 11 and Table 3).

Table 3. The kinetic factors for the removal of ammonium ions by ACDW and LFB.

\begin{tabular}{|c|c|c|c|c|c|}
\hline \multicolumn{3}{|c|}{ First-Order Kinetic } & \multicolumn{3}{|c|}{ Second-Order Kinetic } \\
\hline Adsorbent & $K_{1}(1$ min $)$ & $R^{2}$ & $\mathrm{q}_{\mathrm{e}}$ Calc. (mg.g ${ }^{-1}$ ) & $\mathrm{K}_{2}\left(\mathrm{~g} \cdot \mathrm{mg}^{-1} \cdot \mathrm{min}^{-1}\right)$ & $R^{2}$ \\
\hline ACWD & 122.24 & 0.337 & 1.65 & 0.604 & 0.999 \\
\hline LFB & 0.0034 & 0.239 & 3.379 & 0.295 & 0.996 \\
\hline
\end{tabular}

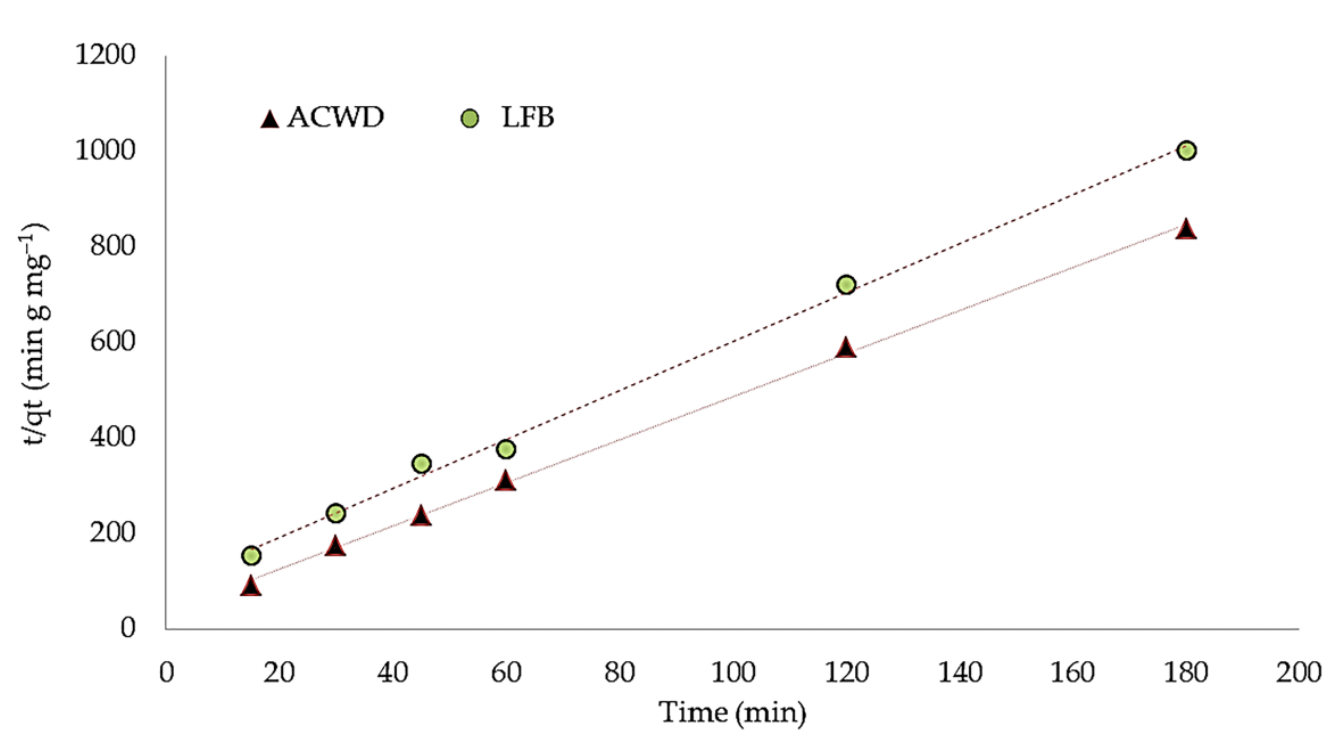

Figure 11. Pseudo-second-order kinetics of ammonium using whole biomass (ACDW) and lipid-free biomass (LFB) of Arthrospira platensis.

\subsection{Bacterial Count}

Today, algal cells are recognized to produce many water-soluble natural pigments such as phycobiliproteins, carotenoids, phycoerythrin, and chlorophyll, which are important in many industries as antimicrobial and antioxidant agents [63], biofertilizer [64-67], aquaculture [68-70], food supplements [71], pharmaceuticals and nutraceuticals [72], and bioremediation $[31,73]$. There are many types of algae that are broadly known to produce intra- and extracellular metabolites with activity against fungal, bacterial, and viral pathogens [74], due to their high content of lipids and fatty acids $[5,75,76]$. The present work evaluated the effects of different forms of A. platensis (ACDW and LFB) on the bacterial count of aquaculture wastewater (RAW) on agar media. The results of treating aquaculture wastewater (RAW) with LFB and ACDW in terms of the bacterial count of each group are presented in Table 4 and Figure 12. The number of bacterial cells was high in all tested groups, exceeding $300 \mathrm{CFU}$, except for the LFB-RAW group, with $<100 \mathrm{CFU}$ (Figure 12 and Table 4). 
Table 4. Bacterial count as a result of treatment of real aquaculture wastewater using LFB and ACDW.

\begin{tabular}{cc}
\hline Bacterial Count & Groups \\
\hline Higher than $300 \mathrm{CFU}$ & LFB \\
\hline Less than $100 \mathrm{CFU}$ & LFB-RAW \\
\hline Higher than $300 \mathrm{CFU}$ & ACDW \\
\hline Higher than $300 \mathrm{CFU}$ & ACDW-RAW \\
\hline Higher than $300 \mathrm{CFU}$ & RAW \\
\hline
\end{tabular}

LFB: lipid-free biomass, LFB-RAW: real aquaculture wastewater treated with LFB, ACDW: Arthrospira complete dry weight, ACDW-RAW: real aquaculture wastewater treated with ACDW, RAW: real aquaculture wastewater
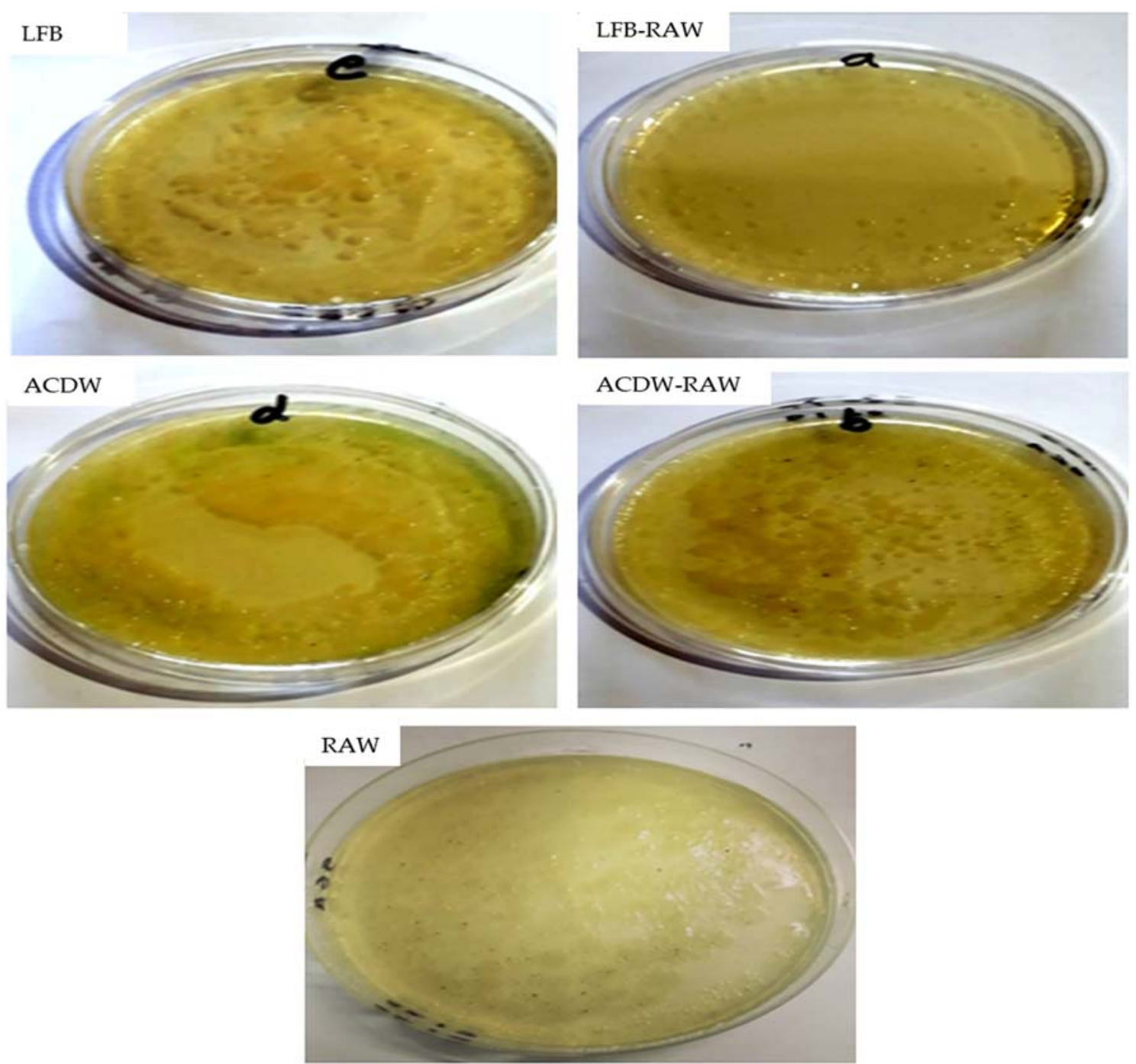

Figure 12. Bacterial count on agar media of all groups: LFB: lipid-free biomass, LFB-RAW: real aquaculture wastewater treated with LFB, ACDW: Arthrospira complete dry weight, ACDW-RAW: real aquaculture wastewater treated with ACDW, RAW: real aquaculture wastewater.

Compared to LFB-RAW (which had a lower bacterial count of $<100 \mathrm{CFU}$ ), all other tested groups showed a bacterial count of $>300 \mathrm{CFU}$. This finding may be attributed to the lipid extraction process from $A$. platensis biomass, whereas LFB-RAW was treated by LFB which was a biodiesel byproduct of $A$. platensis biomass. This result indicates that the extraction of lipids from Arthrospira improved its efficiency and ability to inhibit bacterial growth and multiplication on agar media. The extraction process is well known to increase the surface area of the algal cell due to disruption of the cell walls, resulting in 
the internal organelles and structures such as the cytoplasm being available on the external surfaces. Moreover, this mechanism leads to greater involvement and attachment of water to the intracellular algal voids, intercellular constituents, and superficial algal surfaces. This increases the exposure area of biomass, resulting in improved bacterial inhibition. Previously, A. platensis was evaluated for many medical and pharmaceutical applications due to its intracellular and extracellular polysaccharide molecules which have potential activities against various viral infections including HIV and human cytomegalovirus [77]. Moreover, A. platensis extracts showed a high inhibitory effect against bacterial species such as different Vibrio species (V. anguillarum, V. lentus, V. parahaemolyticus, V. alginolyticus, $V$. splendidus, and V. scophthalmi), different Streptococcus species (S. pyogenes and S. aureus), E. coli, and P. aeruginosa [78], in addition to antifungal properties against $C$. albicans and Aspergillus flavus [79].

\subsection{Rotifer Experiment}

Rotifer B. plicatilis is the biggest zooplankton group in water ecosystems and is of particular importance as a live feed in marine hatcheries [80,81]. In aquatic ecosystems, the zooplankton population can be influenced by many environmental conditions such as temperature, oxygen demand, $\mathrm{pH}$, predation, and competition $[82,83]$, as well as nutrient loading [84]. Figure 13 shows the rotifer population growth, rotifer mortality, rotifer female egg-carrying population, and the mortality of rotifer female egg-carrying population using different concentrations of the studied biomass.

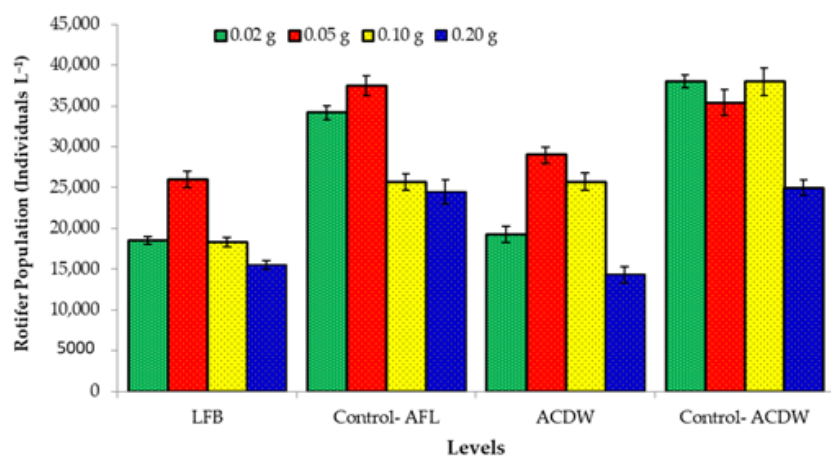

(a)

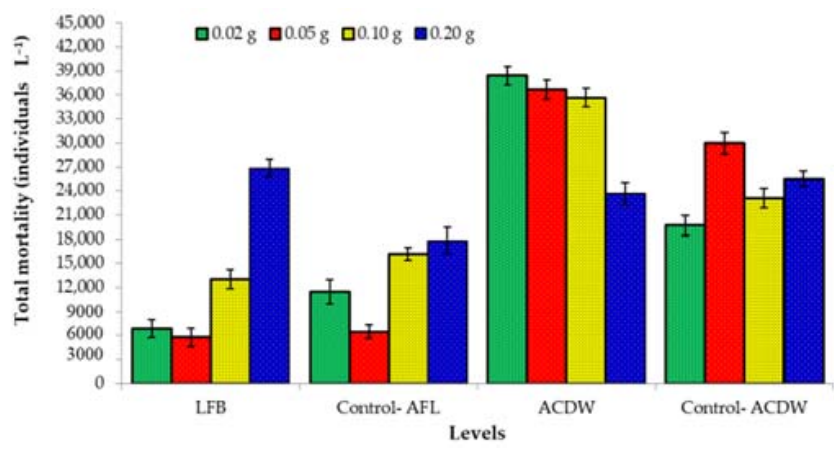

(c)

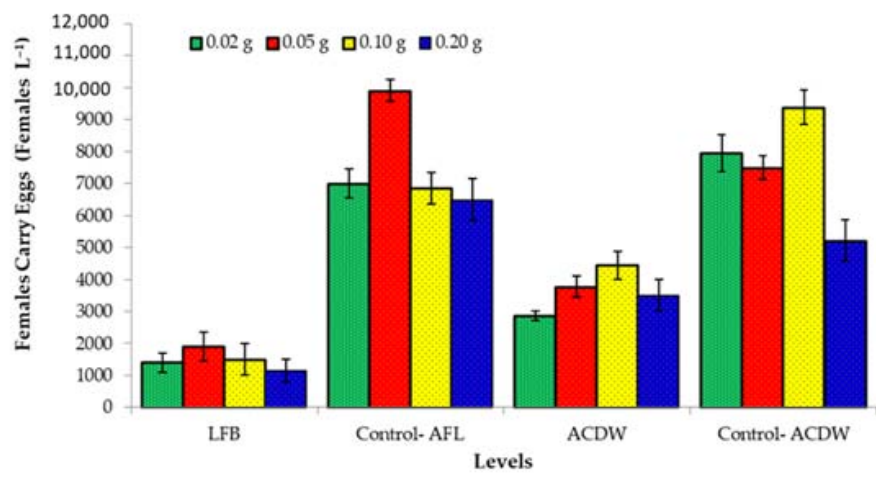

(a)

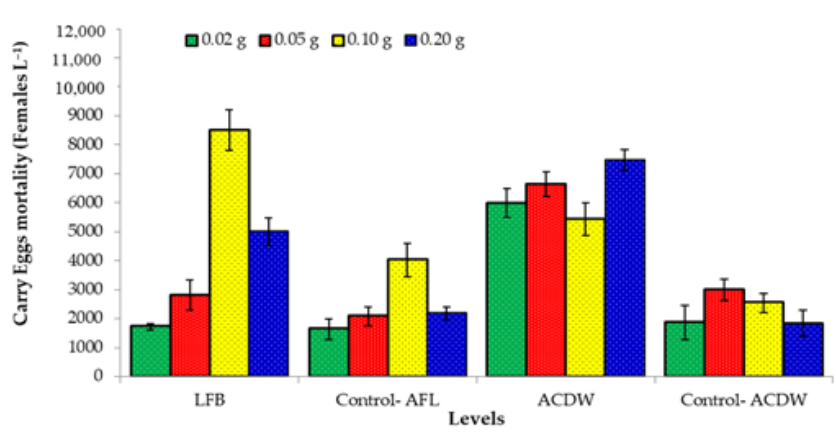

(d)

Figure 13. Effect of several levels of cyanobacterial strain Arthrospira platensis NIOF17/003 (LFB and ACDW) saturated with ammonium ions removed from aquaculture wastewater, compared to the same traditional levels of $A$. platensis as control (LFB-Control and ACDW-Control) on the Brachionus plicatilis population, the population of females carrying eggs, total rotifer mortality, and mortality of the females carrying eggs ((a-d), respectively).

Compared with the control levels of $A$. platensis (LFB-Control and ACDW-Control), all levels of $A$. platensis saturated with ammonium ions that were removed from aquaculture wastewater led to a reduction in the rotifer population, as well as a decrease in the popula- 
tion of females carrying eggs (Figure 13a,b), whereas it increased the total rotifer mortality and the mortality of females carrying eggs (Figure 13c,d). At all LFB and ADCW levels, the highest rotifer population and population of females carrying eggs was achieved at $0.05 \mathrm{~g}$ LFB (26,000 and $1900 \mathrm{ind} \cdot \mathrm{L}^{-1}$, respectively) and $0.10 \mathrm{~g} \mathrm{ACDB}\left(25,700\right.$ and $4435 \mathrm{ind} \cdot \mathrm{L}^{-1}$, respectively). On the other hand, the lowest rotifer population and population of females carrying eggs were achieved at $0.20 \mathrm{~g}$ of either LFB $\left(15,500\right.$ and $1150 \mathrm{ind} \cdot \mathrm{L}^{-1}$, respectively) or ACDB $\left(14,300\right.$ and 3500 ind. $\left.\cdot \mathrm{L}^{-1}\right)$.

To the best of our knowledge, the current study is the first work reporting the potential of ammonia-loaded microalgae biomass as a feed source for rotifers. The study concluded that the sensitivity of marine rotifer B. plicatilis to ammonia concentration was due to a reduced rotifer population and population of females carrying eggs, as well as increased rotifer mortality. Due to ammonia from nutrients in the marine environment influencing marine life, zooplankton communities respond to a wide variety of disturbances, including nutrient loading [84].

\subsection{Comparison of $\mathrm{NH}_{4}-\mathrm{N}$ Elimination by Various Species of Microalgae}

According to recent studies, microalgal systems can efficiently treat many kinds of ammonium-containing wastewaters, as presented in Table 5.

Table 5. Comparison of $\mathrm{NH}_{4}-\mathrm{N}$ removal by different species of microalgae.

\begin{tabular}{ccc}
\hline Species (Microalgae) & $\mathbf{N H}_{4}-\mathbf{N ~ R e m o v a l}$ & Reference \\
\hline Spirulina (Arthrospira) & $84-96 \%$ & {$[85]$} \\
\hline Spirulina sp. & $79 \%$ & {$[86]$} \\
\hline Spirulina platensis & $80 \%$ & {$[87]$} \\
\hline Chlorella sp. & $18 \%$ & {$[11]$} \\
\hline Scenedesmus sp. & $71-92.8 \%$ & {$[88]$} \\
\hline Scenedesmus obliquus & $66-73 \%$ & {$[27]$} \\
\hline Chlorella sorokiniana & $75 \%$ & {$[89]$} \\
\hline Arthrospira platensis (ACDW) & $64 \%$ & This study \\
\hline Arthrospira platensis (LFB) & $89 \%$ & This study \\
\hline
\end{tabular}

\section{Conclusions}

This study examined the potential application of Arthrospira platensis NIOF17/003 complete dry weight (ACDW) and lipid-free biomass (LFB) as low-cost, readily available, highly stable, and environmentally friendly sorbents for the removal of ammonium ions $\left(\mathrm{NH}_{4}{ }^{+}\right)$from synthetic aqueous solution, as well as its applicability to real aquaculture wastewater. In addition, this study evaluated the effect of the adsorbents ACDW and LFB on the bacterial count in aquaculture wastewater. Furthermore, the use of ammonia-laden ACDW and LFB was examined as a feed source for a marine rotifer (Brachionus plicatilis). The adsorption of ammonia onto $A$. platensis in a synthetic aqueous solution was examined using a batch system with respect to the initial ammonia concentration, adsorbent dose, $\mathrm{pH}$, and contact time in the aqueous solution. Maximum removal was found after $2 \mathrm{~h}$ at $\mathrm{pH} 8$ and 6 for ACWD and LFB, respectively, with an optimal adsorbent dose of $0.1 \mathrm{~g}$ at $10 \mathrm{mg} \cdot \mathrm{L}^{-1}$ ammonium ions. However, the removal of ammonium using ACDW and LFB in the synthetic aqueous solution $(64.24 \%$ and $89.68 \%$, respectively) was higher than that of the real aquaculture effluents $(25.70 \%$ and $37.80 \%$, respectively). The maximum ammonium ion adsorption capacity $\left(\mathrm{q}_{\max }=0.379\right.$ and $\left.0.745 \mathrm{mg} \cdot \mathrm{g}^{-1}\right)$ was obtained for ACWD and LFB, respectively. The Freundlich and Langmuir models agreed well with the equilibrium sorption results. The obtained data exhibited that the appropriate kinetic models for both ACWD and LFB were well described with high correlation coefficients by the second-order equations. On the other hand, as a result of the treatment of aquaculture 
wastewater (RAW) with LFB and ACDW, the bacterial count of LFB, ACDW, ACDW-RAW, and RAW groups was $>300 \mathrm{CFU}$, whereas that for LFB-RAW as $<100 \mathrm{CFU}$. The study concluded that $B$. plicatilis was sensitive to $A$. platensis biomass loaded with ammonia. Lastly, the results in this work confirmed that the biomass of $A$. platensis is a promising candidate for ammonia removal from aquaculture wastewater, with potential utilization as a dry feed for rotifer B. plicatilis in marine hatcheries.

Author Contributions: Conceptualization, M.A., A.E.A., A.M.M.H. and A.T.M.; methodology, M.A., A.E.A., A.M.M.H., A.T.M. and H.S.; software, M.A., A.E.A., A.M.M.H. and A.T.M.; validation, A.T.M., K.M.A. and H.S.; formal analysis, M.A., A.E.A., H.S., and A.M.M.H.; investigation, M.A., A.E.A., A.M.M.H., A.T.M., H.S. and D.A.; resources, M.A., A.E.A., A.M.M.H., A.T.M., K.M.A. and D.A.; data curation, M.A., A.E.A., A.M.M.H., A.T.M. and D.A.; writing—original draft preparation, M.A., A.E.A., K.M.A., A.M.M.H. and A.T.M.; writing-review and editing, M.A., A.E.A., A.M.M.H., K.M.A. and A.T.M.; visualization, K.M.A., D.A., M.A., A.E.A. and A.T.M.; supervision, A.E.A., A.T.M. and K.M.A.; project administration, M.A.; funding acquisition, K.M.A., D.A. and A.T.M. All authors have read and agreed to the published version of the manuscript.

Funding: This study was funded by the Taif University Researchers Supporting Project number TURSP-2020/267, Taif University, Taif, Saudi Arabia.

Institutional Review Board Statement: Not applicable.

Informed Consent Statement: Not applicable.

Data Availability Statement: The data presented in this study are available on request from the corresponding authors.

Acknowledgments: The authors are grateful to the Taif University Researchers Supporting Project number TURSP-2020/267, Taif University, Taif, Saudi Arabia.

Conflicts of Interest: The authors declare no conflict of interest.

\section{References}

1. Mook, W.; Chakrabarti, M.; Aroua, M.K.; Khan, G.; Ali, B.; Islam, S.; Abu Hassan, M. Removal of total ammonia nitrogen (TAN), nitrate and total organic carbon (TOC) from aquaculture wastewater using electrochemical technology: A review. Desalination 2012, 285, 1-13. [CrossRef]

2. Zhimiao, Z.; Xiao, Z.; Zhufang, W.; Xinshan, S.; Mengqi, C.; Mengyu, C.; Yinjiang, Z. Enhancing the pollutant removal performance and biological mechanisms by adding ferrous ions into aquaculture wastewater in constructed wetland. Bioresour. Technol. 2019, 293, 122003. [CrossRef]

3. Qin, G.; Liu, C.C.; Richman, N.H.; Moncur, J.E. Aquaculture wastewater treatment and reuse by wind-driven reverse osmosis membrane technology: A pilot study on Coconut Island, Hawaii. Aquac. Eng. 2005, 32, 365-378. [CrossRef]

4. Turcios, A.E.; Papenbrock, J. Sustainable Treatment of Aquaculture Effluents-What Can We Learn from the Past for the Future? Sustainability 2014, 6, 836-856. [CrossRef]

5. Abomohra, A.E.-F.; El-Hefnawy, M.E.; Wang, Q.; Huang, J.; Li, L.; Tang, J.; Mohammed, S. Sequential bioethanol and biogas production coupled with heavy metal removal using dry seaweeds: Towards enhanced economic feasibility. J. Clean. Prod. 2021, 316, 128341. [CrossRef]

6. Haider, S.; Park, S.-Y. Preparation of the electrospun chitosan nanofibers and their applications to the adsorption of $\mathrm{Cu}(\mathrm{II})$ and $\mathrm{Pb}$ (II) ions from an aqueous solution. J. Membr. Sci. 2009, 328, 90-96. [CrossRef]

7. Seruga, P.; Krzywonos, M.; Pyżanowska, J.; Urbanowska, A.; Pawlak-Kruczek, H.; Łukasz, N. Removal of Ammonia from the Municipal Waste Treatment Effluents using Natural Minerals. Molecules 2019, 24, 3633. [CrossRef]

8. Salbitani, G.; Carfagna, S. Ammonium Utilization in Microalgae: A Sustainable Method for Wastewater Treatment. Sustainability 2021, 13, 956. [CrossRef]

9. Cheng, W.-P.; Chen, P.-H.; Yu, R.-F.; Ho, W.-N. Treating ammonium-rich wastewater with sludge from water treatment plant to produce ammonium alum. Sustain. Environ. Res. 2016, 26, 63-69. [CrossRef]

10. Liu, Y.; Ngo, H.H.; Guo, W.; Peng, L.; Wang, D.; Ni, B. The roles of free ammonia (FA) in biological wastewater treatment processes: A review. Environ. Int. 2019, 123, 10-19. [CrossRef]

11. Fito, J.; Alemu, K. Microalgae-bacteria consortium treatment technology for municipal wastewater management. Nanotechnol. Environ. Eng. 2019, 4, 4. [CrossRef]

12. Curtin, K.; Fitzpatrick, B. Biological Nutrient Removal; Minnesota Pollution Control Agency: St Paul, MN, USA, 2011.

13. Rezaei, H.; Rastegar, S.; Naseri, S. Application of Chitosan and Activated Carbon Nano-composite in Removal of Nitrite, Phosphate, and Ammonia from Aquaculture Wastewater. Avicenna J. Environ. Heal. Eng. 2019, 6, 106-112. [CrossRef] 
14. Wang, S.; Uzoejinwa, B.B.; Abomohra, A.E.-F.; Wang, Q.; He, Z.; Feng, Y.; Zhang, B.; Hui, C.-W. Characterization and pyrolysis behavior of the green microalga Micractinium conductrix grown in lab-scale tubular photobioreactor using Py-GC/MS and TGA/MS. J. Anal. Appl. Pyrolysis 2018, 135, 340-349. [CrossRef]

15. Almarashi, J.Q.; El-Zohary, S.E.; Ellabban, M.; Abomohra, A.E.-F. Enhancement of lipid production and energy recovery from the green microalga Chlorella vulgaris by inoculum pretreatment with low-dose cold atmospheric pressure plasma (CAPP). Energy Convers. Manag. 2020, 204, 112314. [CrossRef]

16. Lee, S.-J.; Go, S.; Jeong, G.-T.; Kim, S.-K. Oil production from five marine microalgae for the production of biodiesel. Biotechnol. Bioprocess Eng. 2011, 16, 561-566. [CrossRef]

17. Hayashi, T.; Hayashi, K. Calcium spirulan, an inhibitor of enveloped virus replication, from a blue green alga Spirulina platensis. J. Nat. Prod. 1996, 59, 83-87. [CrossRef]

18. Kumar, V.; Bhatnagar, A.K.; Srivastava, J.N. Antibacterial activity of crude extracts of Spirulina platensis and its structural elucidation of bioactive compound. J. Med. Plants Res. 2011, 5, 7043-7048.

19. Khan, M.; Shobha, J.C.; Mohan, I.K.; Naidu, M.U.R.; Prayag, A.; Kutala, V.K. Spirulina attenuates cyclosporine-induced nephrotoxicity in rats. J. Appl. Toxicol. 2006, 26, 444-451. [CrossRef]

20. Dotto, G.; Lima, E.; Pinto, L. Biosorption of food dyes onto Spirulina platensis nanoparticles: Equilibrium isotherm and thermodynamic analysis. Bioresour. Technol. 2012, 103, 123-130. [CrossRef]

21. El Moselhy, K.M.; Azzem, M.A.; Amer, A.; Prol, A.E. Al Adsorption of Cu (II) and Cd (II) from Aqueous Solution by Using Rice Husk Adsorbent. Phys. Chem. Indian J. 2017, 12, 109.

22. Farahdiba, A.U.; Budiantoro, W.; Yulianto, A. Ammonia removal from Yogyakarta Domestic Wastewater (WWTP-SEWON) by microalgae reactor with $\mathrm{CO}_{2}$ addition. IOP Conf. Ser. Earth Environ. Sci. 2019, 245, 012019. [CrossRef]

23. Kim, J.; Lingaraju, B.P.; Rheaume, R.; Lee, J.-Y.; Siddiqui, K.F. Removal of ammonia from wastewater effluent by chlorella vulgaris. Tsinghua Sci. Technol. 2010, 15, 391-396. [CrossRef]

24. Abbas, E.M.; Ali, F.S.; Desouky, M.G.; Ashour, M.; El-Shafei, A.; Maaty, M.M.; Sharawy, Z.Z. Novel comprehensive molecular and ecological study introducing coastal mud shrimp (Solenocera crassicornis) recorded at the Gulf of suez, Egypt. J. Mar. Sci. Eng. 2021, 9, 9. [CrossRef]

25. Griffiths, E.W. DigitalCommons @ USU Removal and Utilization of Wastewater Nutrients for Algae Biomass and Biofuels. 2009. Available online: https:/ / digitalcommons.usu.edu/etd/631/ (accessed on 10 September 2021).

26. Converti, A.; Scapazzoni, S.; Lodi, A.; Carvalho, J.C.M. Ammonium and urea removal by Spirulina platensis. J. Ind. Microbiol. Biotechnol. 2006, 33, 8-16. [CrossRef]

27. Voltolina, D. Nitrogen removal and recycling by Scenedesmus obliquus in semicontinuous cultures using artificial wastewater and a simulated light and temperature cycle. Bioresour. Technol. 2005, 96, 359-362. [CrossRef]

28. Lu, Q.; Zhou, W.; Min, M.; Ma, X.; Ma, Y.; Chen, P.; Zheng, H.; Doan, Y.; Liu, H.; Chen, C.; et al. Mitigating ammonia nitrogen deficiency in dairy wastewaters for algae cultivation. Bioresour. Technol. 2016, 201, 33-40. [CrossRef]

29. Kang, J. Mitigation of ammonia gas from animal house using microalgae. In Mitigation of Ammonia Gas From Animal House Using Microalgae; 2018. Available online: https: / /lib.dr.iastate.edu/etd/12782/ (accessed on 10 September 2021).

30. Zaki, M.; Ashour, M.; Heneash, A.; Mabrouk, M.; Alprol, A.; Khairy, H.; Nour, A.; Mansour, A.; Hassanien, H.; Gaber, A.; et al. Potential Applications of Native Cyanobacterium Isolate (Arthrospira platensis NIOF17/003) for Biodiesel Production and Utilization of Its Byproduct in Marine Rotifer (Brachionus plicatilis) Production. Sustainability 2021, 13, 1769. [CrossRef]

31. Alprol, A.; Heneash, A.; Ashour, M.; Abualnaja, K.; Alhashmialameer, D.; Mansour, A.; Sharawy, Z.; Abu-Saied, M.; Abomohra, A. Potential Applications of Arthrospira platensis Lipid-Free Biomass in Bioremediation of Organic Dye from Industrial Textile Effluents and Its Influence on Marine Rotifer (Brachionus plicatilis). Materials 2021, 14, 4446. [CrossRef] [PubMed]

32. Zarrouk, C. Contribution a l'etude d'une Cyanophycee. Influence de Divers Facteurs Physiques et Chimiques sur la Croissance et la Photosynthese de Spirulina Mixima. Master's Thesis, University of Paris, Paris, France, 1966.

33. Federation, A.; Association, A. Standard Methods for the Examination of Water and Wastewater; American Public Health Association (APHA): Washington, DC, USA, 2005.

34. Grasshoff, K.; Kremling, K.; Ehrhardt, M. Methods of Sea Water Analysis, 3rd ed.; Weinheim, Ed.; Wiley-VCH: New York, NY, USA, 1999.

35. Ghoneim, M.M.; El-Desoky, H.S.; El-Moselhy, K.M.; Amer, A.; El-Naga, E.H.A.; Mohamedein, L.; Al-Prol, A.E. Removal of cadmium from aqueous solution using marine green algae, Ulva lactuca. Egypt. J. Aquat. Res. 2014, 40, 235-242. [CrossRef]

36. Freundlich, H.M.F. Over the adsorption in solution. J. Phys. Chem. 1906, 57, 1100-1107.

37. Langmuir, I. The constitution and fundamental properties of solids and liquids. Part II.-Liquids. J. Frankl. Inst. 1917, $184,721$. [CrossRef]

38. Halsey, G. Physical Adsorption on Non-Uniform Surfaces. J. Chem. Phys. 1948, 16, 931-937. [CrossRef]

39. Kumar, Y.P.; King, P.; Prasad, V. Removal of copper from aqueous solution using Ulva fasciata sp.-A marine green algae. J. Hazard. Mater. 2006, 137, 367-373. [CrossRef] [PubMed]

40. Al-Aoh, H.A.; Yahya, R.; Maah, M.J.; Bin Abas, M.R. Adsorption of methylene blue on activated carbon fiber prepared from coconut husk: Isotherm, kinetics and thermodynamics studies. Desalination Water Treat. 2013, 52, 6720-6732. [CrossRef]

41. Ho, Y.; McKay, G. Pseudo-second order model for sorption processes. Process. Biochem. 1999, 34, 451-465. [CrossRef] 
42. Yahaya, T.; Doherty, V.; Akinola, O.; Shamsudeen, A. Heavy metal profiles and microbial counts of selected sachet water brands in Birnin Kebbi Metropolis, Nigeria. Ife J. Sci. 2019, 21, 229. [CrossRef]

43. Ashour, M.; Elshobary, M.E.; El-Shenody, R.; Kamil, A.; El-Fatah, A. Evaluation of a native oleaginous marine microalga Nannochloropsis oceanica for dual use in biodiesel production and aquaculture feed. Biomass Bioenergy 2019, 120, $439-447$. [CrossRef]

44. Inyinbor, A.; Adekola, F.; Olatunji, G. Kinetics, isotherms and thermodynamic modeling of liquid phase adsorption of Rhodamine B dye onto Raphia hookerie fruit epicarp. Water Resour. Ind. 2016, 15, 14-27. [CrossRef]

45. Gong, R.; Ding, Y.; Liu, H.; Chen, Q.; Liu, Z. Lead biosorption and desorption by intact and pretreated spirulina maxima biomass. Chemosphere 2005, 58, 125-130. [CrossRef]

46. Cardoso, N.F.; Pinto, R.B.; Lima, E.C.; Calvete, T.; Amavisca, C.V.; Royer, B.; Cunha, M.L.; Fernandes, T.H.; Pinto, I.S. Removal of remazol black B textile dye from aqueous solution by adsorption. Desalination 2011, 269, 92-103. [CrossRef]

47. Calvete, T.; Lima, E.C.; Cardoso, N.F.; Dias, S.L.; Pavan, F.A. Application of carbon adsorbents prepared from the Brazilian pine-fruit-shell for the removal of Procion Red MX 3B from aqueous solution-Kinetic, equilibrium, and thermodynamic studies. Chem. Eng. J. 2009, 155, 627-636. [CrossRef]

48. Abualnaja, K.; Alprol, A.; Abu-Saied, M.; Mansour, A.; Ashour, M. Studying the Adsorptive Behavior of Poly(Acrylonitrileco-Styrene) and Carbon Nanotubes (Nanocomposites) Impregnated with Adsorbent Materials towards Methyl Orange Dye. Nanomaterials 2021, 11, 1144. [CrossRef] [PubMed]

49. Abualnaja, K.; Alprol, A.; Abu-Saied, M.; Ashour, M.; Mansour, A. Removing of Anionic Dye from Aqueous Solutions by Adsorption Using of Multiwalled Carbon Nanotubes and Poly (Acrylonitrile-styrene) Impregnated with Activated Carbon. Sustainability 2021, 13, 7077. [CrossRef]

50. Peterson, H.C.; Healey, F.P.; Wagernann, R. Metal toxicity to algae: A highly pH dependent phenomenon. Can. J. Fish Aquat. Sci. 1984, 41, 974-979. [CrossRef]

51. Abualnaja, K.; Alprol, A.; Ashour, M.; Mansour, A. Influencing Multi-Walled Carbon Nanotubes for the Removal of Ismate Violet 2R Dye from Wastewater: Isotherm, Kinetics, and Thermodynamic Studies. Appl. Sci. 2021, 11, 4786. [CrossRef]

52. Montalvo, S.; Huiliñir, C.; Borja, R.; Sánchez, E.; Herrmann, C. Application of zeolites for biological treatment processes of solid wastes and wastewaters-A review. Bioresour. Technol. 2020, 301, 122808. [CrossRef]

53. Putra, W.P.; Kamari, A.; Najiah, S.; Yusoff, M.; Ishak, C.F. Biosorption of Cu (II), Pb (II) and Zn (II) Ions from Aqueous Solutions Using Selected Waste Materials: Adsorption and Characterisation Studies. J. Encapsulation Adsorpt. Sci. 2014, $2014,25-35$. [CrossRef]

54. Nogueira, S.M.S.; Junior, J.S.; Maia, H.D.; Saboya, J.P.S.; Farias, W.R.L. Use of Spirulina platensis in treatment of fish farming wastewater. Rev. Ciência Agronômica 2018, 49, 599-606. [CrossRef]

55. Liu, Y.; Lv, J.; Feng, J.; Liu, Q.; Nan, F.; Xie, S. Treatment of real aquaculture wastewater from a fishery utilizing phytoremediation with microalgae. J. Chem. Technol. Biotechnol. 2019, 94, 900-910. [CrossRef]

56. Wuang, S.C.; Khin, M.C.; Chua, P.Q.D.; Luo, Y.D. Use of Spirulina biomass produced from treatment of aquaculture wastewater as agricultural fertilizers. Algal Res. 2016, 15, 59-64. [CrossRef]

57. Shen, Y.; Gao, J.; Li, L. Municipal wastewater treatment via co-immobilized microalgal-bacterial symbiosis: Microorganism growth and nutrients removal. Bioresour. Technol. 2017, 243, 905-913. [CrossRef] [PubMed]

58. Delgadillo-Mirquez, L.; Lopes, F.; Taidi, B.; Pareau, D. Nitrogen and phosphate removal from wastewater with a mixed microalgae and bacteria culture. Biotechnol. Rep. 2016, 11, 18-26. [CrossRef]

59. Blaby-Haas, C.E.; Merchant, S.S. The ins and outs of algal metal transport. Biochim. Biophys. Acta BBA-Bioenerg. 2012, 1823, 1531-1552. [CrossRef]

60. Gaignard, C.; Laroche, C.; Pierre, G.; Dubessay, P.; Delattre, C.; Gardarin, C.; Gourvil, P.; Probert, I.; Dubuffet, A.; Michaud, P. Screening of marine microalgae: Investigation of new exopolysaccharide producers. Algal Res. 2019, 44, 101711. [CrossRef]

61. Lau, P.S.; Lee, H.Y.; Tsang, C.K.; Tam, N.Y.; Wong, Y.S. Effect of Metal Interference, pH and Temperature on Cu and Ni Biosorption by Chlorella Vulgaris and Chlorella Miniata. Environ. Technol. 1999, 20, 953-961. [CrossRef]

62. Wang, L.; Xiao, H.; He, N.; Sun, D.; Duan, S. Biosorption and Biodegradation of the Environmental Hormone Nonylphenol by Four Marine Microalgae. Sci. Rep. 2019, 9, 5277. [CrossRef]

63. Elshobary, M.E.; El-Shenody, R.A.; Ashour, M.; Zabed, H.M.; Qi, X. Antimicrobial and antioxidant characterization of bioactive components from Chlorococcum minutum. Food Biosci. 2020, 35, 100567. [CrossRef]

64. Ashour, M.; El-Shafei, A.A.; Khairy, H.M.; Abd-Elkader, D.Y.; Mattar, M.A.; Alataway, A.; Hassan, S.M. Effect of Pterocladia capillacea Seaweed Extracts on Growth Parameters and Biochemical Constituents of Jew's Mallow. Agronomy 2020, 10, 420. [CrossRef]

65. Ashour, M.; Hassan, S.; Elshobary, M.; Ammar, G.; Gaber, A.; Alsanie, W.; Mansour, A.; El-Shenody, R. Impact of Commercial Seaweed Liquid Extract $\left(\mathrm{TAM}^{\circledR}\right)$ Biostimulant and Its Bioactive Molecules on Growth and Antioxidant Activities of Hot Pepper (Capsicum annuum). Plants 2021, 10, 1045. [CrossRef]

66. Hassan, S.; Ashour, M.; Soliman, A.; Hassanien, H.; Alsanie, W.; Gaber, A.; Elshobary, M. The Potential of a New Commercial Seaweed Extract in Stimulating Morpho-Agronomic and Bioactive Properties of Eruca vesicaria (L.) Cav. Sustainability 2021, 13 , 4485. [CrossRef] 
67. Hassan, S.; Ashour, M.; Sakai, N.; Zhang, L.; Hassanien, H.; Gaber, A.; Ammar, G. Impact of Seaweed Liquid Extract Biostimulant on Growth, Yield, and Chemical Composition of Cucumber (Cucumis sativus). Agriculture 2021, 11, 320. [CrossRef]

68. Ashour, M.; Mabrouk, M.M.; Abo-Taleb, H.A.; Sharawy, Z.; Ayoub, H.F.; Van Doan, H.; Davies, S.J.; El-Haroun, E.; Goda, A.M.-A. A liquid seaweed extract (TAM $\AA$ ) improves aqueous rearing environment, diversity of zooplankton community, whilst enhancing growth and immune response of Nile tilapia, Oreochromis niloticus, challenged by Aeromonas hydrophila. Aquaculture 2021, 543, 736915. [CrossRef]

69. Ashour, M.; Mabrouk, M.M.; Ayoub, H.F.; El-Feky, M.M.; Zaki, S.Z.; Hoseinifar, S.H.; Rossi, W.; Van Doan, H.; El-Haroun, E.; Goda, A.M.-S. Effect of dietary seaweed extract supplementation on growth, feed utilization, hematological indices, and non-specific immunity of Nile Tilapia, Oreochromis niloticus challenged with Aeromonas hydrophila. Environ. Boil. Fishes 2020, 32, 3467-3479. [CrossRef]

70. Sharawy, Z.Z.; Ashour, M.; Abbas, E.; Ashry, O.; Helal, M.; Nazmi, H.; Kelany, M.; Kamel, A.; Hassaan, M.; Rossi, W., Jr.; et al. Effects of dietary marine microalgae, Tetraselmis suecica, on production, gene expression, protein markers and bacterial count of Pacific white shrimp Litopenaeus vannamei. Aquac. Res. 2020, 51, 2216-2228. [CrossRef]

71. El-Shenody, R.A.; Ashour, M.; Ghobara, M.M.E. Evaluating the chemical composition and antioxidant activity of three Egyptian seaweeds: Dictyota dichotoma, Turbinaria decurrens, and Laurencia obtusa. Braz. J. Food Technol. 2019, 22, 22. [CrossRef]

72. Shao, W.; Ebaid, R.; El-Sheekh, M.; Abomohra, A.; Eladel, H. Pharmaceutical applications and consequent environmental impacts of Spirulina (Arthrospira): An overview. Grasas Aceites 2019, 70, 292. [CrossRef]

73. Han, S.; Jin, W.; Chen, Y.; Tu, R.; Abomohra, A.E.-F. Enhancement of Lipid Production of Chlorella Pyrenoidosa Cultivated in Municipal Wastewater by Magnetic Treatment. Appl. Biochem. Biotechnol. 2016, 180, 1043-1055. [CrossRef]

74. Noaman, N.H.; Fattah, A.; Khaleafa, M.; Zaky, S.H. Factors affecting antimicrobial activity of Synechococcus leopoliensis. Microbiol. Res. 2004, 159, 395-402. [CrossRef] [PubMed]

75. Abomohra, A.E.-F.; Zheng, X.; Wang, Q.; Huang, J.; Ebaid, R. Enhancement of biodiesel yield and characteristics through in-situ solvo-thermal co-transesterification of wet microalgae with spent coffee grounds. Bioresour. Technol. 2021, 323, 124640. [CrossRef]

76. Abomohra, A.E.-F.; El-Sheekh, M.; Hanelt, D. Pilot cultivation of the chlorophyte microalga Scenedesmus obliquus as a promising feedstock for biofuel. Biomass- Bioenergy 2014, 64, 237-244. [CrossRef]

77. Rechter, S.; König, T.; Auerochs, S.; Thulke, S.; Walter, H.; Dörnenburg, H.; Walter, C.; Marschall, M. Antiviral activity of Arthrospira-derived spirulan-like substances. Antivir. Res. 2006, 72, 197-206. [CrossRef]

78. Kokou, F.; Makridis, P.; Kentouri, M.; Divanach, P.; Makridis, P. Antibacterial activity in microalgae cultures. Aquac. Res. 2011, 43, 1520-1527. [CrossRef]

79. Moraes de Souza, M.; Prietto, L.; Ribeiro, A.C.D.; de Souza, T.B.-F.E. Assessment of the antifungal activity of Spirulina platensis phenolic extract against Aspergillus flavus. Cienc. Agrotecnologia 2011, 35, 1050-1058. [CrossRef]

80. Ashour, M.; Abo-Taleb, H.; Abou-Mahmoud, M.; El-Feky, M.M.M. Effect of the integration between plankton natural productivity and environmental assessment of irrigation water, El-Mahmoudia Canal, on aquaculture potential of Oreochromis niloticus. Turk. J. Fish. Aquat. Sci. 2018, 18, 1163-1175. [CrossRef]

81. Alprol, A.; Heneash, A.; Soliman, A.; Ashour, M.; Alsanie, W.; Gaber, A.; Mansour, A. Assessment of Water Quality, Eutrophication, and Zooplankton Community in Lake Burullus, Egypt. Diversity 2021, 13, 268. [CrossRef]

82. Heneash, A.M.; Alprol, A.E.; El-Hamid, H.T.A.; Khater, M.; El Damhogy, K.A. Assessment of water pollution induced by anthropogenic activities on zooplankton community in Mariout Lake using statistical simulation. Arab. J. Geosci. 2021, 14, 641. [CrossRef]

83. Abo-Taleb, H.; Ashour, M.; El-Shafei, A.; Alataway, A.; Maaty, M.M.; Abo-Taleb, H. Biodiversity of Calanoida Copepoda in Different Habitats of the North-Western Red Sea (Hurghada Shelf). Water 2020, 12, 656. [CrossRef]

84. Doson, S. Predicting crustacean zooplankton species richness. Limnol. Oceanog. 1992, 37, 848-856. [CrossRef]

85. Olguín, E.J.; Galicia, S.; Mercado, G.; Pérez, T. Annual productivity of Spirulina (Arthrospira) and nutrient removal in a pig wastewater recycling process under tropical conditions. Environ. Boil. Fishes 2003, 15, 249-257. [CrossRef]

86. Zhou, W.; Li, Y.; Gao, Y.; Zhao, H. Nutrients removal and recovery from saline wastewater by Spirulina platensis. Bioresour. Technol. 2017, 245, 10-17. [CrossRef]

87. Boussiba, S. Ammonia Uptake in the Alkalophilic Cyanobacterium Spirulina platensis1. Plant. Cell Physiol. 1989, 30, 303-308. [CrossRef]

88. Pham, T.-L.; Bui, M.H. Removal of Nutrients from Fertilizer Plant Wastewater Using Scenedesmus sp.: Formation of Bioflocculation and Enhancement of Removal Efficiency. J. Chem. 2020, 2020, 8094272. [CrossRef]

89. Kobayashi, N.; Noel, E.A.; Barnes, A.; Watson, A.; Rosenberg, J.N.; Erickson, G.; Oyler, G.A. Characterization of three Chlorella sorokiniana strains in anaerobic digested effluent from cattle manure. Bioresour. Technol. 2013, 150, 377-386. [CrossRef] [PubMed] 